The undersigned, appointed by the Dean of the Graduate School, have examined the thesis entitled

MEASUREMENTS OF THE EFFECT OF HUMIDITY ON RADIO-AEROSOL PENETRATION THROUGH ULTRAFINE CAPILLARIES

presented by Craig Cullen

a candidate for the degree of Master of Science and hereby certify that in their opinion it is worthy of acceptance.
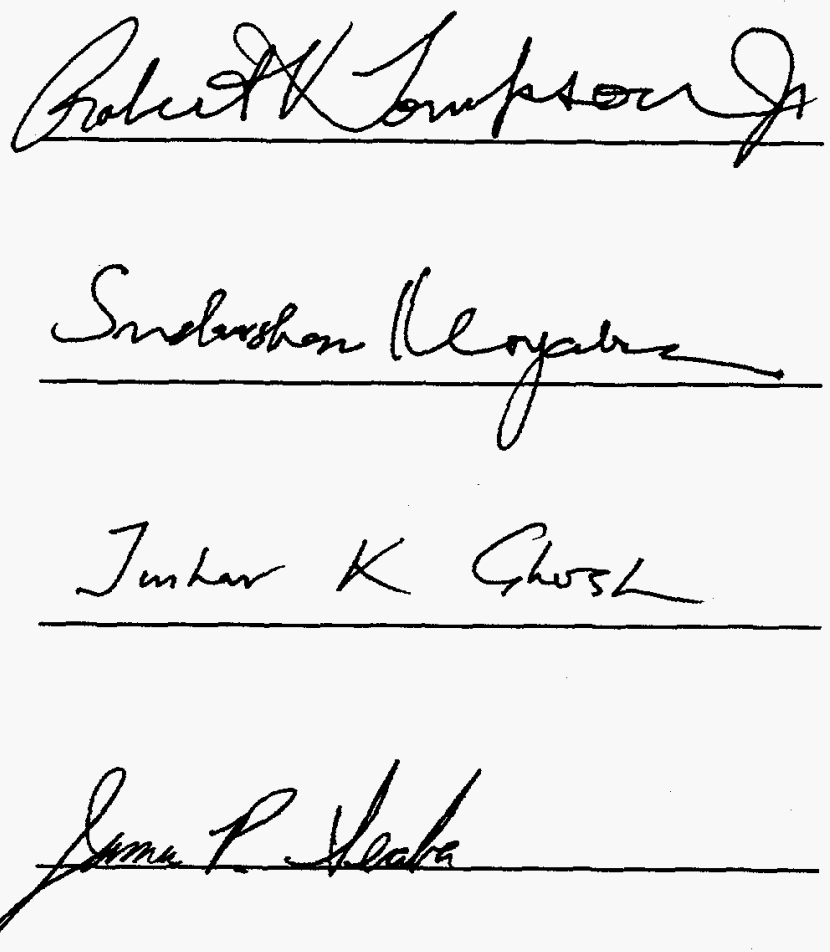


\section{DOE/OR/00033-T732}

\section{MEASUREMENTS OF THE EFFECT OF HUMIDITY ON RADIO-AEROSOL PENETRATION THROUGH ULTRAFINE CAPILLARIES}

\section{A Thesis}

Presented to

the Faculty of the Graduate School

University of Missouri-Columbia

In Partial Fulfillment

of the Requirements for the Degree

Master of Science

by

CRAIG CULLEN

Dr. Robert Tompson, Thesis Advisor

Dr. Sudarshan Loyalka, Co-Advisor

Dr. Tushar Ghosh, Co-Advisor

AUGUST 1996 


\section{DISCLAIMER}

This report was prepared as an account of work sponsored by an agency of the United States Government. Neither the United States Government nor any agency thereof, nor any of their empioyees, makes any warranty, express or implied, or assumes any legal liability or responsibility for the accuracy, completeness, or usefulness of any information, apparatus, product, or process disclosed, or represents that its use would not infringe privately owned rights. Reference herein to any specific commercial product, process, or service by trade name, trademark, manufacturer, or otherwise does not necessarily constitute or imply its endorsement, recommeadation, or favoring by the United States Government or any agency thereof. The views and opinions of authors expressed herein do not necessarily state or reflect those of the United States Government or any agency thereof. 


\section{DISCLAIMER}

Portions of this document may be illegible electronic image products. Images are produced from the best available original document. 


\section{ACKNOWLEDGMENTS}

This research was performed under appointment to the Applied Health Physics Fellowship Program administered by Oak Ridge Institute for Science and Education for the U.S. Department of Energy.

I would like to give my thanks and appreciation to Dr. Sudarshan Loyalka whose guidance, support, and patience made the completion of this research possible.

Special thanks to the other members of my thesis committee, Dr. Robert Tompson, Dr. Tushar Ghosh, and Dr. James Seaba, for their support and technical insight which were invaluable to this research.

Also, I wish to express my gratitude to Khalid Mousley, Perapong Tekasakul, and Avigit Varma for their technical support.

I would like to acknowledge the administrative support from Gayla Neumeyer, Sharon Young, Thomas Richmond, and Rose Etta Cox whose help made my experience at the University of Missouri-Columbia a pleasant one.

Finally, I would like to thank my family for their encouragement and support throughout my education. 


\title{
MEASUREMENTS OF THE EFFECT OF HUMIDITY ON RADIO-AEROSOL PENETRATION THROUGH ULTRAFINE CAPILLARIES
}

\section{Craig Cullen}

\author{
Dr. R.V. Tompson, Thesis Advisor
}

\begin{abstract}
The purpose of this research was to examine the effects of humidity on radio-aerosol penetration through ultrafine capillaries. A number of tests were conducted at relative humidities of $20 \%, 50 \%$, and $80 \%$, with sampling times of 20,40 , and $60 \mathrm{~min}$. The radio-aerosol consisted of polystyrene particles with a diameter of $0.1 \mu \mathrm{m}$. The ultrafine capillaries had a diameter of $250 \mu \mathrm{m}$. The data from these tests varied significantly. These results made the identification of radio-aerosol penetration trends inconclusive. The standard deviation for all penetration data ranged from $3 \%$ to $30 \%$.

The results of this study suggest that a better control of the experimental parameters was needed to obtain more accurate data from experiments associated with radio-aerosol penetration in the presence of moisture. The experimental parameters that may have contributed to the wide variance of data, include aerosol flow, radio-aerosol generation, capillary characteristics, humidity control, and radiation measurements. It was the uncertainty of these parameters that contributed to the poor data which made conclusive deductions about radio-aerosol penetration dependence on humidity difficult.
\end{abstract}




\section{LIST OF TABLES}

Table 1: Previous theoretical capillary studies 7

Table 2: Previous experimental capillary studies ……...................................... 8

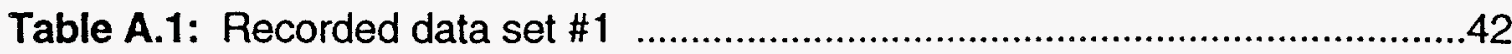

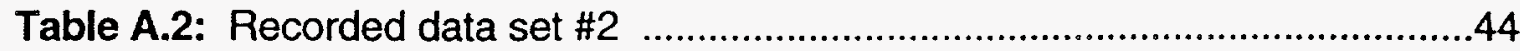

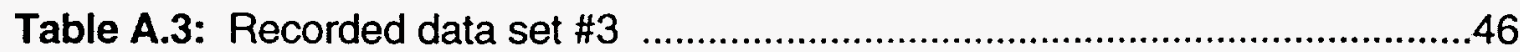

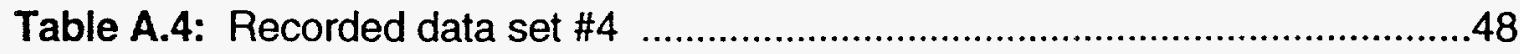

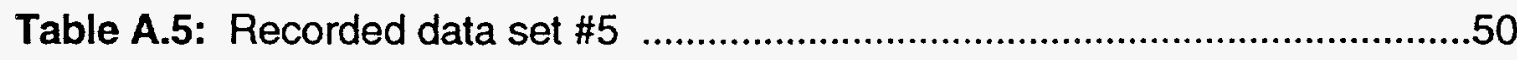

Table A.6: Recorded data set \#6 ………………............................................52

Table A.7: Recorded data set \#7 .....................................................................54

Table C.1: Penetration and error for $20 \mathrm{~min}$ sampling time at various humidities

Table C.2: Penetration and error for $40 \mathrm{~min}$ sampling time at various humidities

Table C.3: Penetration and error for $60 \mathrm{~min}$ sampling time at various humidities

Table C.4: Penetration and error for various sampling times at a relative humidity of $50 \%$ 62 


\section{LIST OF FIGURES}

Figure 1: A transportation cask for spent fuel assemblies

Figure 2: A schematic of PSRC's radio-aerosol test facility 14

Figure 3: Principal decay scheme of Rn-222 (Kinsara 1992) 15

Figure 4: Humidifier - This set-up was used to humidify radio-aerosol from the mixing chamber. The humidified radio-aerosol was then directed into the main chamber

Figure 5: Capillary Appartus - The vacuum valve connections were attached to the main chamber, simultaneously. Humidified radio-aerosol entered both capillaries and were collected by filters in the filter holders. (Wyman 1995)....18

Figure 6: Data acquisition system for radio-aerosol measurements. (Kinsara 1992)

Figure 7: Typical particle size distribution determined by a TSI DMPS system for $0.1 \mu \mathrm{m}$ diameter aerosol particles

Figure 8a: Radio-aerosol penetration dependence on relative humidity for radio-aerosol particles $(0.1 \mu \mathrm{m}$ dia.) passing through an ultrafine capillary (250 $\mu \mathrm{m}$ dia.) for $20 \mathrm{~min}$ 27

Figure 8b: Radio-aerosol penetration dependence on relative humidity with error bars for radio-aerosol particles $(0.1 \mu \mathrm{m}$ dia.) passing through an ultrafine capillary $(250 \mu \mathrm{m} \mathrm{dia}$.) for $20 \mathrm{~min}$ .28

Figure 9a: Radio-aerosol penetration dependence on relative humidity for radio-aerosol particles $(0.1 \mu \mathrm{m}$ dia.) passing through an ultrafine capillary ( $250 \mu \mathrm{m} \mathrm{dia.)}$ for $40 \mathrm{~min}$ 29

Figure 9b: Radio-aerosol penetration dependence on relative humidity with error bars for radio-aerosol particles $(0.1 \mu \mathrm{m}$ dia.) passing through an ultrafine capillary (250 $\mu \mathrm{m}$ dia.) for $40 \mathrm{~min}$

Figure 10a: Radio-aerosol penetration dependence on relative humidity for radio-aerosol particles $(0.1 \mu \mathrm{m}$ dia.) passing through an ultrafine capillary (250 $\mu \mathrm{m} \mathrm{dia.)} \mathrm{for} 60 \mathrm{~min}$

Figure 10b: Radio-aerosol penetration dependence on relative humidity with error bars for radio-aerosol particles $(0.1 \mu \mathrm{m}$ dia.) passing through an ultrafine capillary ( $250 \mu \mathrm{m}$ dia.) for $60 \mathrm{~min}$ .32 
Figure 11a: Radio-aerosol penetration dependence on time for radio-aerosol particles $(0.1 \mu \mathrm{m}$ dia.) passing through an ultrafine capillary $(250 \mu \mathrm{m}$ dia.) at a relative humidity of $50 \%$

Figure 11b: Radio-aerosol penetration dependence on time with error bars for radio-aerosol particles $(0.1 \mu \mathrm{m}$ dia.) passing through an ultrafine capillary ( $250 \mu \mathrm{m}$ dia.) at a relative humidity of $50 \%$ .34

Figure A.1: Particle size distribution of 0.1 micron diameter particles for data in Table A.1

Figure A.2: Particle size distribution of 0.1 micron diameter particles for data in Table A.2 45

Figure A.3: Particle size distribution of 0.1 micron diameter particles for data in Table A.3

Figure A.4: Particle size distribution of 0.1 micron diameter particles for data in Table A.4 49

Figure A.5: Particle size distribution of 0.1 micron diameter particles for data in Table A.5

Figure A.6: Particle size distribution of 0.1 micron diameter particles for data in Table A.6 . .53

Figure A.7: Particle size distribution of 0.1 micron diameter particles for data in Table A.7 55 


\section{TABLE OF CONTENTS}

ACKNOWLEDGEMENTS ii

ABSTRACT .iii

LIST OF TABLES iv

LIST OF FIGURES ..$v$

\section{CHAPTER}

1. INTRODUCTION 1

2. LITERATURE REVIEW

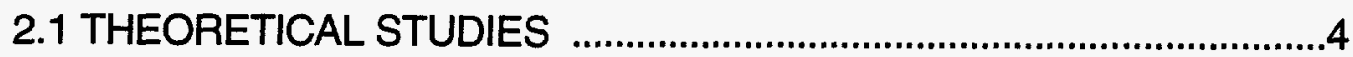

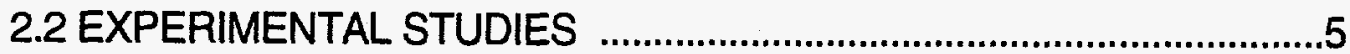

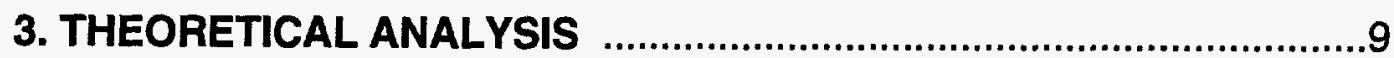

3.1 AEROSOL DEPOSITION IN A CHAMBER ........................................

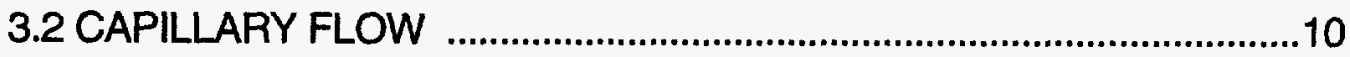

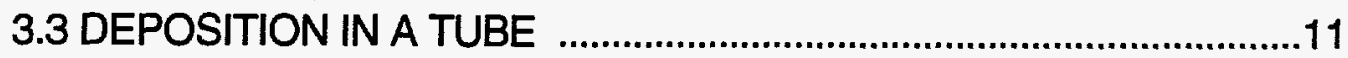

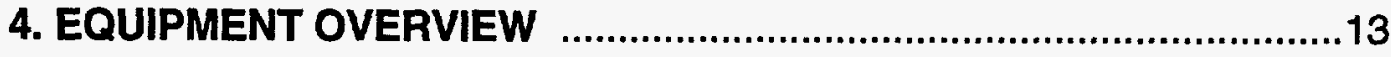

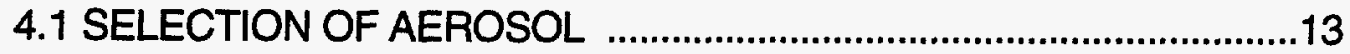

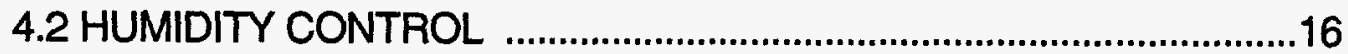

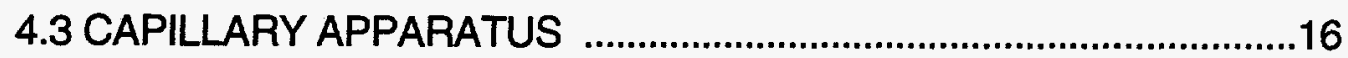

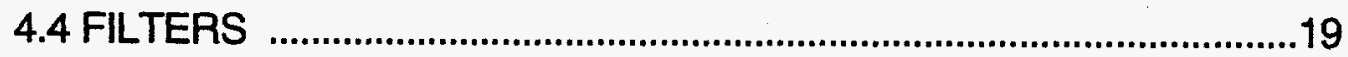

4.5 TEST PREPARATION AND CALIBRATION ...................................19

4.5.1 MAIN CHAMBER TEST …................................................19

4.5.2 DETECTOR EFFICIENCY …................................................19

4.5.3 AEROSOL PARTICLE INFORMATION ..................................20

4.5.4 FLOW THROUGH SAMPLE CAPILLARY APPARATUS .....20

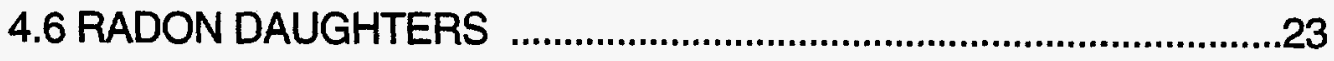

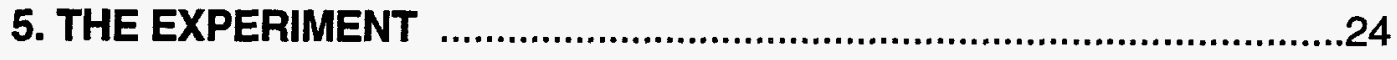

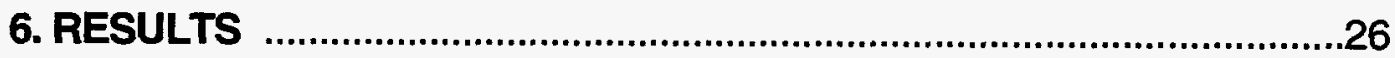




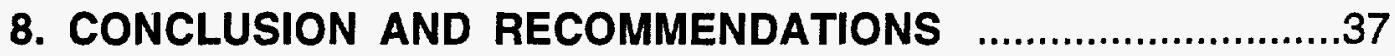

REFERENCES 39

APPENDIX A: RECORDED DATA AND PARTICLE SIZE

DISTRIBUTIONS

APPENDIX B: SAMPLE CALCULATIONS OF PENETRATION AND

ERROR 56

APPENDIX C: VALUES OF PENETRATION AND ERROR .58 


\section{CHAPTER 1 \\ INTRODUCTION}

The handling of high level nuclear waste has been a national concern since the beginning of the environmental movement in the 1960's. Proper disposal of high level radioactive waste is an issue constantly debated among the public and the government. This issue is made more complicated with each passing year as the government commitment to establish a national disposal site for high level nuclear waste is questioned. As part of this endeavor, the Nuclear Regulatory Commission (NRC) in the 1980's began testing and certifying casks for the transportation of high level radioactive waste. A typical transportation cask is shown in Figure 1. The integrity of these casks is essential to the establishment of a safe national nuclear waste transportation policy. Design specifications and performance standards of transportation casks defined by NRC protocol and by other agencies, such as the International Atomic Energy Agency, are stringent.

These specifications require that transportation casks pass strict performance tests. These tests simulate a variety of accident scenarios that might occur during the transportation of a cask filled with nuclear waste. After such tests, transportation casks are examined for the release of radioactive material. Though an obvious rupture may not develop, ultrafine leaks resulting from stress fractures on a microscopic scale are highly possible. Over a significant period of time, radioactive material inside a transportation cask may escape through microscopic leaks into the environment. The rate at which a small leak may occur is affected by many factors such as the pressure inside the cask, the difference between the cask temperature and the ambient temperature, the cask material, the physical characteristics of the radioactive 
material, and the humidity inside the cask relative to the ambient air. It is imperative to properly evaluate the risks associated with the development of ultrafine leaks in order to minimize the benefit/risk costs of this particular problem. This type of evaluation depends upon understanding the transport mechanics of radioactive materials through ultrafine fissures.

The purpose of this research was to examine the effects of humidity on radioactive aerosol penetration through ultrafine capillaries. This research was performed at the Particulate Systems Research Center of the University of Missouri-Columbia. 


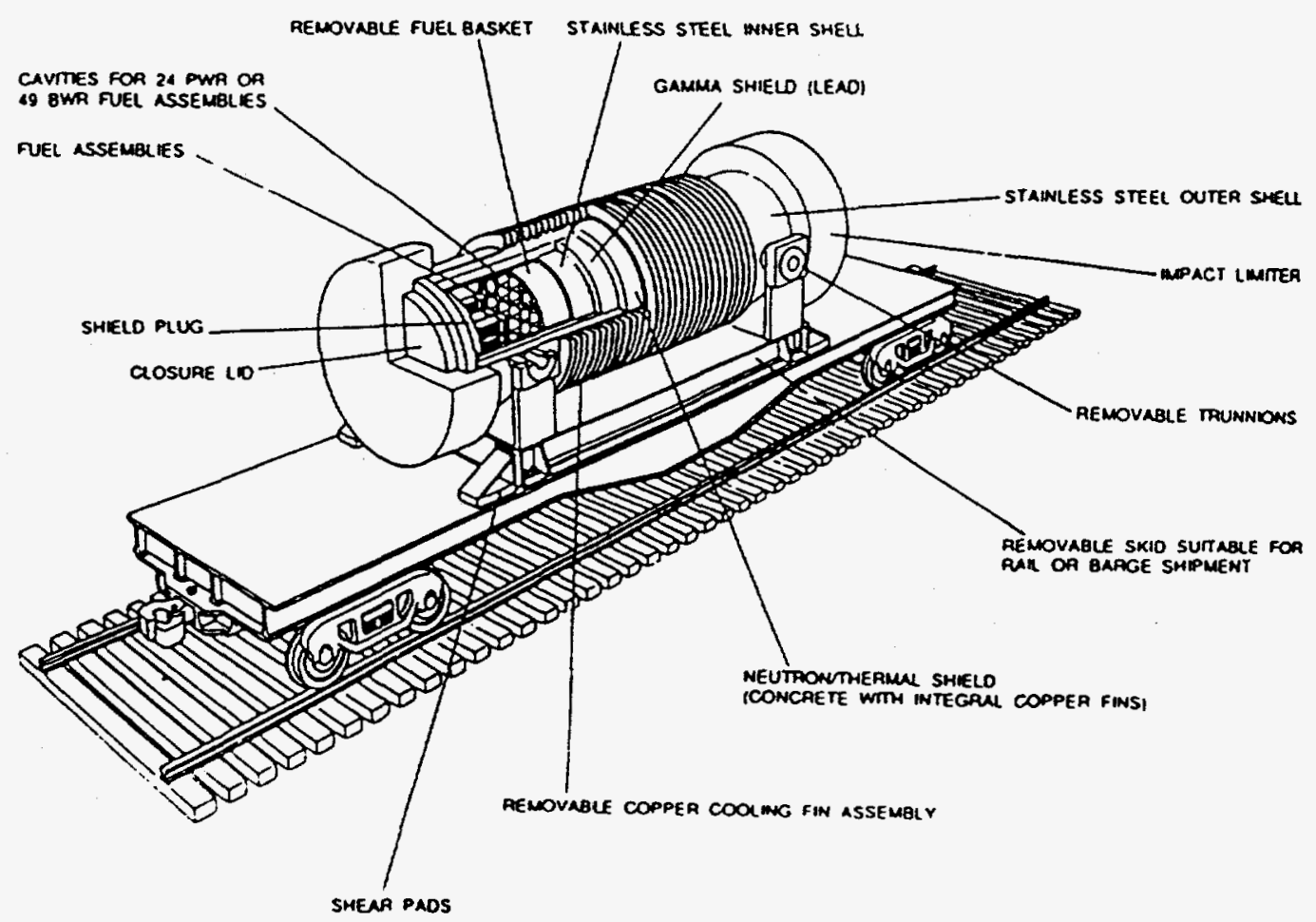

Figure 1: A transportation cask for spent fuel assemblies. (Cochran 1990). 


\section{CHAPTER 2 \\ LITERATURE REVIEW}

Theoretical and experimental studies on aerosol flow through ultrafine capillaries are reviewed in this chapter. Tables 1 and 2 summarize the previous theoretical and experimental studies, respectively. Common mechanisms of aerosol transport through capillaries include diffusion, gravitational sedimentation, inertial impaction, and electrostatic deposition. Diffusion was the dominant transport mechanism for the particular aerosol particle size used in this study.

\subsection{THEORETICAL STUDIES}

Morewitz (1982) developed a model to describe the effects of plugging of fine capillaries due to aerosol flow. His model predicts that aerosols will plug a tube four magnitudes of order faster than if the aerosol is treated as a gas. Plugging tends to occur at the entrance of a capillary. It was also noted that aerosols agglomerate to previously deposited aerosol particles. These agglomerates may become resuspended to form aerosol particles that are larger than the original particles. As a result, the agglomerates tend to plug capillaries faster than the smaller particles.

Stopford and M.G. Williams (1992) did extensive modeling of fine capillary experiments made by Mitchell (1989). These models described the dependence of flow on the capillary orifice. It was observed at the entrance of a capillary that large particles tend to rebound and small particles deposit. Therefore, there exists an optimum flow for each particle diameter. This optimum flow was determined. Maximum penetration through the orifice occurred when the capillary entrance was flush with the surface of the chamber. 
M.M.R. Williams (1993) studied the characteristic parameters of particulate and gas transport through tubes and cracks. These three parameters as defined by Williams are: 1) gas flow through non-uniform cross sectional tubes, 2) deposition of particles onto capillary walls, and 3) deposition rates leading to plugging of the capillary.

Clement (1994) made a detailed analysis of aerosol deposition, flow, and plugging of fine capillaries based on the works of Burton (1993) and Mitchell (1992). Clement discussed the relationship between aerosol concentration and aerosol flow in capillaries.

\subsection{EXPERIMENTAL STUDIES}

Sutter et al. (1980) performed capillary flow experiments that described powder penetration as a function of orifice diameter and chamber pressure. The powder penetration did not exhibit time dependence in a 24 hour period.

Van de Vate (1988) developed a mathematical model to describe the experimental results of aerosol penetration through cracks in concrete. He also briefly discussed aerosol deposition mechanisms such as diffusion, electrophoresis, thermophoresis, diffusiophoresis, gravitational settling, and inertial deposition.

Mitchell, Edwards, and Ball (1990) studied aerosol laminar flow through capillaries and tried "to define the regimes where particle blockage or other mechanisms will prevent leakage." Penetration was a maximum when the internal diameter was large or the capillary length was short. Partial plugging occurred more often then total plugging in the capillary. A linear correlation between penetration and the Reynolds number for ultrafine capillaries was observed.

Aritomi et al. (1993) examined gas flow through capillaries to calculate penetration rates through transportation casks. This examination resulted in an 
empirical correlation for penetration with flow rates of $10^{-4}$ to $0.5 \mathrm{~cm}^{3} \mathrm{~s}^{-1}$.

Morton and Mitchell (1994), after analyzing their experimental results, characterized the effect of plugging at various pressures. Plugging at low pressures, $20 \mathrm{kPa}$ abs., occurred quickly compared to larger pressures, $80 \mathrm{kPa}$ abs. Also, a cyclic pattern of penetration occurred associated with larger pressures. 
Table 1: Previous theoretical capillary studies.

\begin{tabular}{|c|c|c|c|c|}
\hline Authors & $\begin{array}{l}\text { Studies on } \\
\text { which the } \\
\text { theory is } \\
\text { based }\end{array}$ & $\begin{array}{l}\text { Particle } \\
\text { Size }\end{array}$ & $\begin{array}{l}\text { Capillary } \\
\text { Length/ } \\
\text { Capillary } \\
\text { Diameter }\end{array}$ & Comments \\
\hline $\begin{array}{c}\text { Morewitz } \\
1982\end{array}$ & $\begin{array}{c}\text { Not } \\
\text { Available }\end{array}$ & $\begin{array}{c}\text { Not } \\
\text { Available }\end{array}$ & $\begin{array}{l}30 \mathrm{~cm}- \\
1800 \mathrm{~cm} / \\
100 \mu \mathrm{m}- \\
30 \mathrm{~cm}\end{array}$ & $\begin{array}{l}\text { Aerosols } \\
\text { behaved } \\
\text { differently } \\
\text { than gas. }\end{array}$ \\
\hline $\begin{array}{c}\text { Stopford } \\
\text { and M.G. } \\
\text { Williams } \\
1991\end{array}$ & Mitchell 1989 & $0.7-10 \mu \mathrm{m}$ & $\begin{array}{c}50 \mu \mathrm{mm} / \\
20-80 \mu \mathrm{m}\end{array}$ & $\begin{array}{l}\text { Significant orifice } \\
\text { effects } \\
\text { occurred. }\end{array}$ \\
\hline $\begin{array}{c}\text { Stopford } \\
\text { and M.G. } \\
\text { Williams } \\
1992\end{array}$ & $\begin{array}{c}\text { Morton } \\
1991\end{array}$ & $\begin{array}{c}1,3,5 \mu \mathrm{m} \\
\mathrm{CeO}_{2}\end{array}$ & $\begin{array}{c}0.18 \mathrm{~mm} \\
0.3 \mathrm{~mm} / \\
15 \mu \mathrm{m} \\
25 \mu \mathrm{m}\end{array}$ & $\begin{array}{l}\text { Optimum flow for } \\
\text { particle diameter } \\
\text { was determined. }\end{array}$ \\
\hline $\begin{array}{l}\text { M.M.R. } \\
\text { Williams } \\
1993\end{array}$ & $\begin{array}{c}\text { Nelson and } \\
\text { Johnson } 1975\end{array}$ & $\begin{array}{l}\text { 3-5 } \mu \mathrm{m} \\
\text { sodium } \\
\text { carbonate }\end{array}$ & $\begin{array}{l}49-76 \mu \mathrm{mm} / \\
520 \mu \mathrm{m}- \\
1570 \mu \mathrm{m}\end{array}$ & $\begin{array}{l}\text { Plugging effects } \\
\text { were reported. }\end{array}$ \\
\hline $\begin{array}{c}\text { M.M.R } \\
\text { Williams } \\
1993\end{array}$ & $\begin{array}{c}\text { Owarski } \\
1994\end{array}$ & $3-5 \mu \mathrm{m}$ & $\begin{array}{c}8-25 \mathrm{~mm} / \\
48-275 \mu \mathrm{m}\end{array}$ & $\begin{array}{l}\text { Laminar flow } \\
\text { deposition was } \\
\text { studied. }\end{array}$ \\
\hline $\begin{array}{c}\text { Clement } \\
1994\end{array}$ & $\begin{array}{l}\text { Burton } 1993 \\
\text { Mitchell } 1992\end{array}$ & $\begin{array}{c}\text { Not } \\
\text { Available }\end{array}$ & $\begin{array}{c}\text { Not } \\
\text { Available }\end{array}$ & $\begin{array}{l}\text { Complete } \\
\text { deposition and } \\
\text { plugging were } \\
\text { investigated. }\end{array}$ \\
\hline
\end{tabular}


Table 2: Previous experimental capillary studies.

\begin{tabular}{|c|c|c|c|c|}
\hline Authors & $\begin{array}{l}\text { Particle } \\
\text { Size }\end{array}$ & $\begin{array}{l}\text { Capillary } \\
\text { Length/ } \\
\text { Capillary } \\
\text { Diameter }\end{array}$ & $\begin{array}{l}\text { Flow Rate/ } \\
\text { Pressure }\end{array}$ & Comments \\
\hline $\begin{array}{l}\text { Sutter et al. } \\
1980\end{array}$ & $\begin{array}{c}<10 \mu \mathrm{m} \\
\text { depleted } \\
\mathrm{UO}_{2} \\
\text { powder form }\end{array}$ & $\begin{array}{c}0.76 \mathrm{~cm} \\
2.54 \mathrm{~cm} / \\
20-250 \mu \mathrm{m}\end{array}$ & $\begin{array}{c}\text { Not Available/ } \\
6895 \mathrm{kPa}\end{array}$ & $\begin{array}{l}\text { Penetration } \\
\text { depends upon } \\
\text { orifice diameter and } \\
\text { pressure. }\end{array}$ \\
\hline $\begin{array}{c}\text { van de } \\
\text { Vate } 1988\end{array}$ & $\begin{array}{c}0.5-2 \mu \mathrm{m} \\
\text { polystyrene }\end{array}$ & $\begin{array}{l}45 \mathrm{~mm} / \\
0.15 \mathrm{~mm} \\
0.25 \mathrm{~mm}\end{array}$ & $\begin{array}{c}150 \text { to } \\
350 \mathrm{~cm}^{3} \mathrm{~s}^{-1} / \\
3-9 \mathrm{kPa}\end{array}$ & $\begin{array}{l}\text { Gas leaks through } \\
\text { concrete. }\end{array}$ \\
\hline $\begin{array}{l}\text { Mitchell, } \\
\text { Edwards, \& } \\
\text { Ball 1990 }\end{array}$ & $0.5-15 \mu \mathrm{m}$ & $\begin{array}{l}10-50 \mathrm{~mm} / \\
20-80 \mu \mathrm{m}\end{array}$ & $\begin{array}{c}83 \mathrm{~cm}^{3} \mathrm{~s}^{-1} \\
10 \mathrm{kPa}- \\
100 \mathrm{kPa}\end{array}$ & $\begin{array}{l}\text { Linear correlation } \\
\text { between penetration } \\
\text { and Reynolds \#. }\end{array}$ \\
\hline $\begin{array}{l}\text { Aritomi et } \\
\text { al. } 1994\end{array}$ & $\begin{array}{l}\mathrm{He}, \operatorname{Ar}, \mathrm{N}, \\
\text { Air }\end{array}$ & $\begin{array}{l}10 \mathrm{~mm} / \\
24 \mu \mathrm{m} \\
51 \mu \mathrm{m}\end{array}$ & $\begin{array}{c}10^{-4} \text { to } \\
10^{-2} \mathrm{~cm}^{3} \mathrm{~s}^{-1} / \\
0.105 \mathrm{MPa}- \\
1.0 \mathrm{MPa}\end{array}$ & $\begin{array}{l}\text { Gases instead of } \\
\text { aerosols were used. }\end{array}$ \\
\hline $\begin{array}{l}\text { Morton and } \\
\text { Mitchell } \\
1994\end{array}$ & $\begin{array}{l}3 \mu \mathrm{m} \text { glass } \\
\text { particles }\end{array}$ & $\begin{array}{c}19-21 \mathrm{~mm} / \\
28-35 \mu \mathrm{m} \\
\text { glass }\end{array}$ & $\begin{array}{l}\text { Not Available/ } \\
20 \mathrm{kPa}- \\
100 \mathrm{kPa}\end{array}$ & $\begin{array}{l}\text { Plugging dependent } \\
\text { upon pressure. }\end{array}$ \\
\hline
\end{tabular}




\section{CHAPTER 3 \\ THEORETICAL ANALYSIS}

Development of a model for aerosol transport and aerosol deposition is a challenging task since aerosol behavior is influenced by a number of factors, including adhesive forces, particle properties, and environmental properties. The main adhesive forces between aerosol particles and surfaces are van der Waals, electrostatic, and liquid films. These forces are affected by the type of surface material, surface roughness, and surface contamination. Aerosol behavior is also influenced by the material, shape, and size of the suspended particles. Environmental conditions such as temperature and pressure gradients also play a significant role for aerosol deposition in capillaries. As mentioned previously, diffusion is the dominant transport mechanism for deposition of aerosols in this study. However, it was beyond the scope of this project to theoretically address the influences of humidity on aerosol penetration.

\subsection{AEROSOL DEPOSITION IN A CHAMBER}

As described by Kinsara (1992), deposition of aerosols in a chamber with a mixing fan can be expressed by Equation (1a). This equation describes the characteristic turbulence of the flow, settling, and diffusion of the particles in a chamber.

$$
\beta=\left[\frac{4}{\pi}\left(\frac{1}{i}+\frac{1}{h}+\frac{1}{w}\right) \sqrt{k D}\right]
$$

$B$ is the deposition rate constant. The length, height, and width of the chamber are $I, h$, and $w$, respectively. 
$D$ is the diffusion coefficient and $k$ is given by the following expression

$$
k=0.4\left[\frac{\varepsilon}{8 v}\right]^{0.5}
$$

where

$$
\varepsilon=\frac{7.9 \mathrm{~N}^{3} \mathrm{~B}^{5}}{V}
$$

$v$ is the kinematic viscosity of the gas, $\varepsilon$ is the energy dissipation rate per unit mass of fluid, and $\mathrm{N}$ is the fan speed in revolutions per second. The fan blade diameter is $B$, and $V$ is the volume of the chamber.

\subsection{CAPILLARY FLOW}

A fully developed flow in a tube can be expressed as

$$
u(r, x, \theta)=u(r)
$$

In order to describe the laminar flow in a tube one can begin with the continuity Equation (3a) for one dimension.

$$
\frac{\partial(\rho u)}{\partial r}+\frac{\partial \rho}{\partial t}=0
$$

Assuming steady state condition and $\rho$ is constant, the continuity equation becomes

$$
\rho \frac{\partial u}{\partial r}=0
$$

The momentum equation is given by

$$
\rho u \frac{\partial u}{\partial r}=-\frac{\partial P}{\partial x}+\mu \frac{\partial^{2} u}{\partial x^{2}}+\frac{\mu}{r} \frac{\partial}{\partial r}\left[r \frac{\partial u}{\partial r}\right]
$$


Assuming $u$ to be independent of $x$,

$$
\frac{\partial^{2} u}{\partial x^{2}}=0
$$

After substituting Equation (3b) into Equation (4), the resulting equation becomes

$$
\frac{1}{r} \frac{\partial}{\partial r}\left[r \frac{\partial u}{\partial R}\right]=\frac{1}{\mu} \frac{\partial P}{\partial x}
$$

The following boundary conditions may be assumed for the capillary

$$
u(r)=0, \quad \frac{\partial u(0)}{\partial r}=0, \quad \text { and } \quad \frac{\partial P}{\partial x}=\text { constant }
$$

for fully developed flow, solving Equation (5), yields the laminar flow rate in a tube

$$
u(r)=-\left(1-\frac{r^{2}}{R^{2}}\right) \frac{R^{2}}{4 \mu} \frac{d P}{d x}
$$

The total flow rate in a capillary is

$$
Q=2 \pi \int_{0}^{R} u(r) r d r
$$

After substituting Equation (6), the total flow rate is given by

$$
Q=-\frac{\pi R^{4}}{8 \mu} \frac{d P}{d x}
$$

\subsection{DEPOSITION IN A TUBE}

If the flow in a tube is fully developed laminar flow, then the aerosol flux is given by

$$
J=u(r) c(r, x)-D \nabla c(r, x)
$$


where $u$ is the flow velocity, $D$ is the diffusion coefficient and $c$ is the particle concentration. For steady state

$$
\nabla J=0=\frac{\partial}{\partial x}[u(r) c(r, x)]-D \nabla^{2} c(r, x)
$$

and Equation (9) simplifies to

$$
D \frac{1}{r} \frac{\partial}{\partial r}\left[r \frac{\partial c(r, x)}{\partial r}\right]=u(r) \frac{\partial c(r, x)}{\partial x}
$$

Equation (10) may be solved by separation of variables with the following boundary conditions

$$
c(r, x)=0 \text { at } r=R \quad \text { and } \quad \frac{\partial c(r, x)}{\partial r}=0 \text { at } r=0
$$

The penetration through a tube is expressed by Hinds (1982) by the following equation

$$
\text { Penetration }=\frac{\int d A_{c} c(r, x) u(r, x)_{x=1}}{\int d A_{c} c(r, x) u(r, x)_{x=0}} \approx \frac{N_{\text {exit }}}{N_{\text {enter }}}
$$

The penetration may be determined by using the values calculated from Equations (6) and (10). Empirical equations for penetration through tubes for laminar flow are also given in works by Hinds (1982), Williams and Loyalka (1991), and Morton and Mitchell (1994). These empirical equations are only valid within specific ranges of certain physical parameters. 


\section{CHAPTER 4 \\ EQUIPMENT OVERVIEW}

This study was conducted at the Particulate Systems Research Center, University of Missouri-Columbia, using the radio-aerosol test facility. The radioaerosol apparatus consist of several components including an aerosol generator, a radon generator, a testing chamber, a humidifier, a differential mobility particle system, and a data acquisition system. A schematic diagram of the radio-aerosol test facility is shown in Figure 2. A detailed description of the components of the radio-aerosol test facility was given by Kinsara (1992). The instrument calibrations and details of the experiment are discussed in this chapter.

\subsection{SELECTION OF AEROSOL}

In this study, radon daughters were used as the radioactive component of the aerosol used in the experiments. The use of radio-aerosols make quantitative measurements of aerosol penetration possible. Radon is a colorless and odorless gas that is a member of the U-238 decay chain. Radium-226 is the parent of radon which eventually decays to stable Pb-206. Figure 3 shows the decay scheme for the short lived radon daughters with the respective daughters half-lives, modes of decay, and corresponding energies. The significant daughters of radon in this experiment are $\mathrm{Po}-218, \mathrm{~Pb}-214, \mathrm{Bi}$ 214 , and Po-214, which are in the aerosol form.

Radon and its daughters interact with the environment in a variety of ways. They may flow freely, attach to an ambient aerosol, or deposit on a nearby surface (plateout). The two phases of radon daughters are the molecular phase (unattached) and the particle phase (attached). 


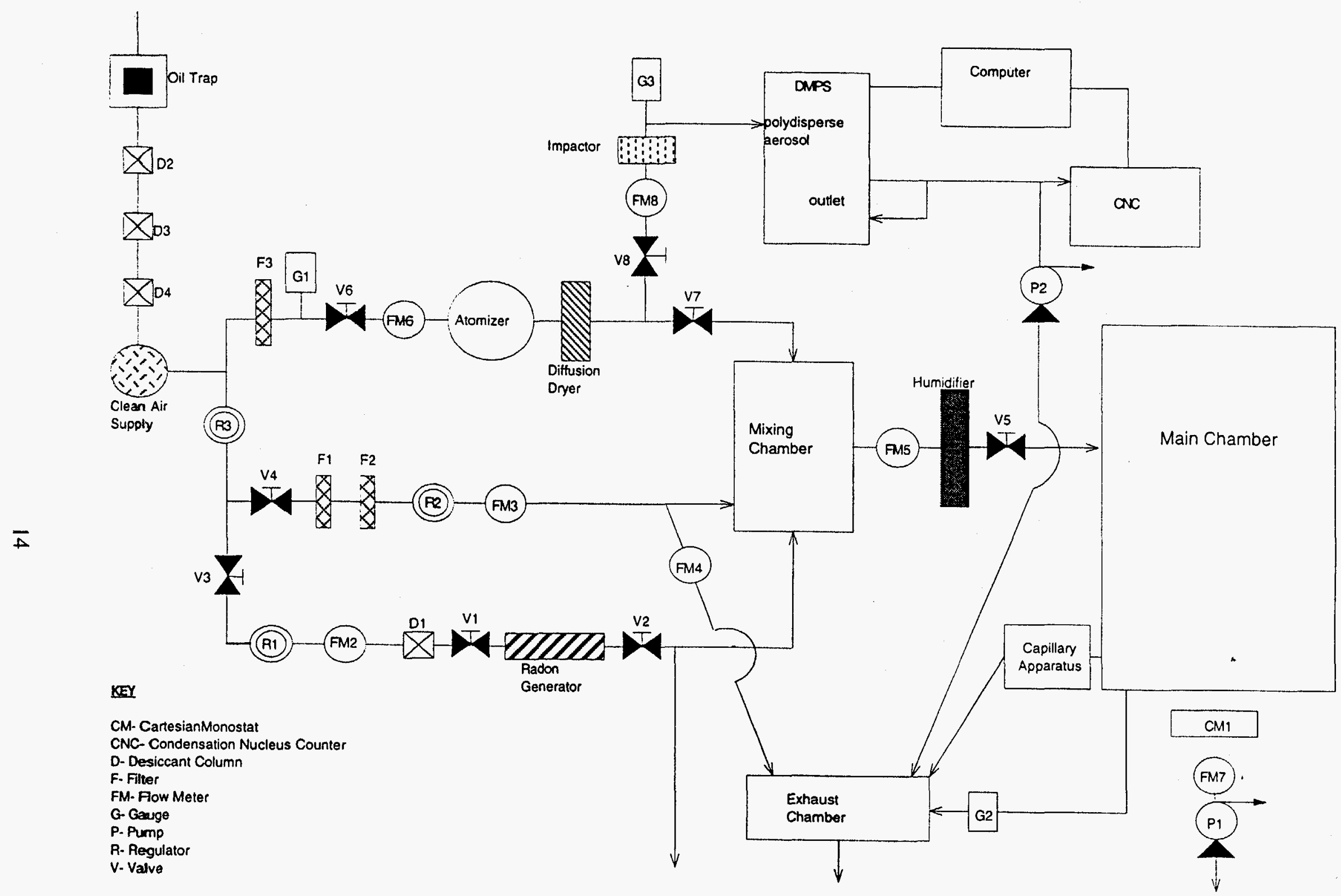

Figure 2: A schematic of PSRC's radio-aerosol test facility. (Wyman 1995). 


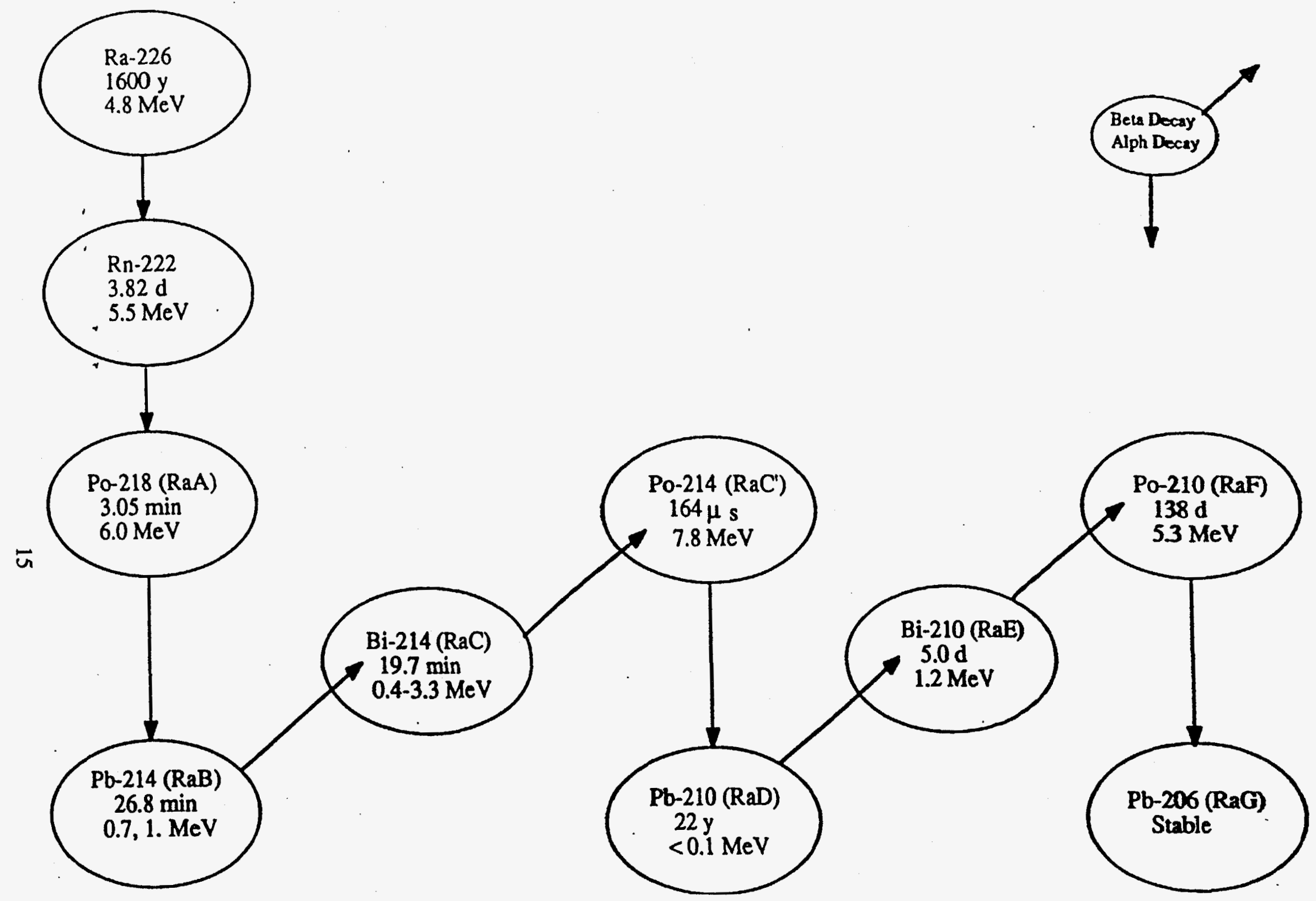

Figure 3: Principal decay scheme of Rn-222. (Kinsara 1992). 
The radon daughters in the molecular phase have very high deposition efficiencies. This makes radon an excellent choice for generating a radioaerosol.

\subsection{HUMIDITY CONTROL}

A humidifier was used to humidify the radio-aerosol. The humidifier consists of a constant temperature water bath and two bubblers (see Figure 4). The bubblers were used in series. The first bubbler contained distilled water. The second bubbler was filled with silica fiber. The water of the bath can be either heated or cooled to a specific temperature, therefore, one can control the bubbler water temperature. The humidity of the radio-aerosol is dependent upon the temperature of the water in the first bubbler. The radio-aerosol became humidified as it passed through the first bubbler. Excess water mist carried over by the radio-aerosol was removed as it passed through the second bubbler. A humidity/temperature sensor (OMEGA model $30 \mathrm{RH} / \mathrm{C}$ ) attached to the main chamber was used to monitor the relative humidity and the temperature inside the chamber.

\subsection{CAPILLARY APPARATUS}

The stainless steel capillaries used in this study were made by RESEEK. These capillaries had an internal diameter of $250 \mu \mathrm{m}$ and had a length of 7.62 $\mathrm{cm}$. Figure 5 shows the sample capillary apparatus for this experiment. The sample capillary apparatus has two capillaries labeled as the inlet (reference) capillary and the outlet (sample) capillary. This apparatus was used to determine the penetration through the sample capillary. 

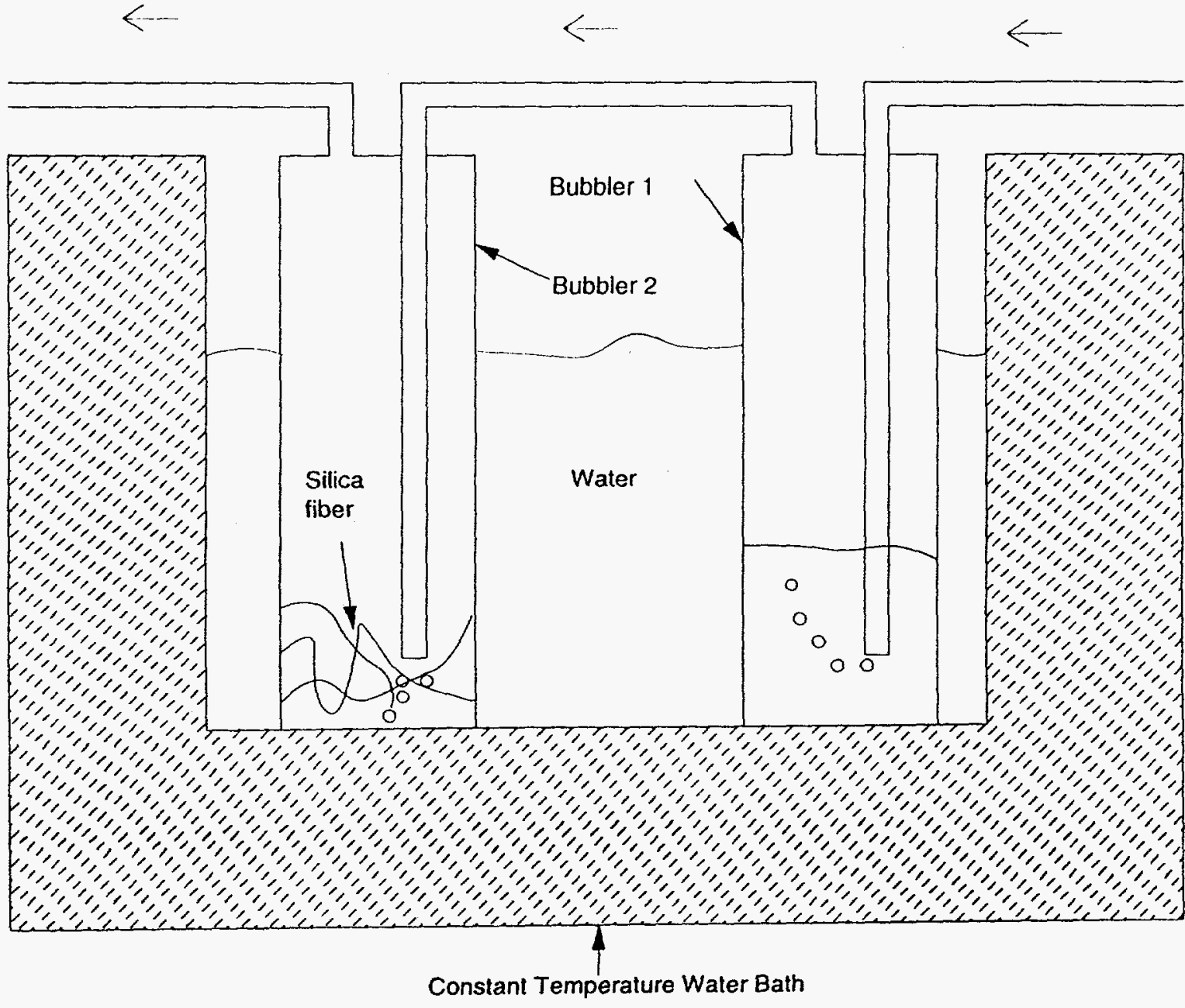

Figure 4: Humidifier - This set-up was used to humidify radio-aerosol from the mixing chamber. The humidified radio-aerosol was then directed into the main chamber. 


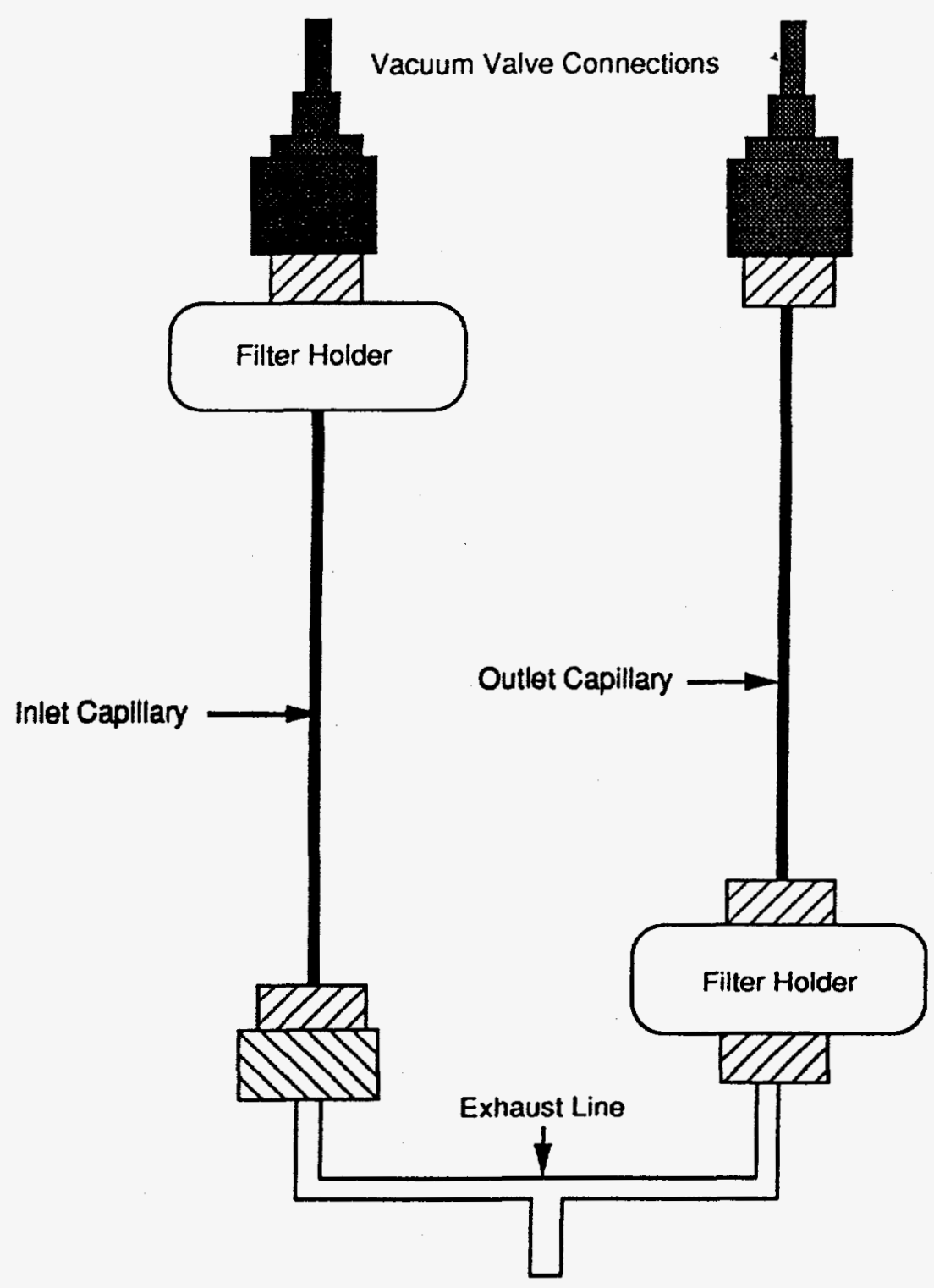

Figure 5: Capillary Apparatus - The vacuum valve connections were attached to the main chamber, simultaneously. Humidified radio-aerosol entered both capillaries and were collected by filters in the filter holders. (Wyman 1995). 
A measurement made at the reference capillary gave the number of particles entering the capillary. Another measurement made at the exit of the sample capillary provided the number of particles exiting the sample capillary. Assuming that both capillaries had a similar geometry, the ratio of the outlet measurement over the inlet measurement provided the penetration of radioaerosol through the sample capillary.

\subsection{FILTERS}

Millipore filters (pore size $0.025 \mu \mathrm{m}$ ) were connected to the capillaries in order to capture the radio-aerosol entering and exiting the capillaries. These filters were $2.54 \mathrm{~cm}$ in diameter. After exposure to the radio-aerosol, the filters were placed in a $\mathrm{ZnS}$ detectors. The $\mathrm{ZnS}$ detectors measured the radioactivity on the filters which was proportional to the amount of radio-aerosol particles that deposited on the filters.

\subsection{TEST PREPARATION AND CALIBRATION}

In order to assure that the experimental data were consistent and to minimize the statistical error of the results, various equipment calibrations were made prior to testing. A number of performance tests were also conducted before and during testing to maintain the integrity of the experimental data.

\subsubsection{MAIN CHAMBER TEST}

The main chamber was checked for leaks to ensure its integrity. The main chamber was pressurized to $220 \mathrm{kPa}$. Over a 24 hour period, the change in pressure was $10 \mathrm{kPa}$. This was a satisfactory performance since the duration of the longest test was three hours at an average pressure of $180 \mathrm{kPa}$.

\subsubsection{DETECTOR EFFICIENCY}

The efficiency of the $\mathrm{ZnS}$ alpha detectors was determined by using a $\mathrm{Pu}$ 238 calibration source (Ludlum model 13-4d). Figure 6 shows a schematic of the Data Acquisition System. Detector 1 had an efficiency of $45.2 \%$ and that of 
detector 2 was $45.0 \%$. Detectors 3,4 , and 5 were not used in this study.

\subsubsection{AEROSOL PARTICLE INFORMATION}

The generated aerosols were made from a solution of polystyrene produced by DUKE. The particles had an average diameter of $0.1 \mu \mathrm{m}$. However, the particle size distribution of the generated aerosols were determined by using a Differential Mobility Particle System (DMPS) to ensure that the aerosol particle size was consistent throughout the experiment . A typical particle size distribution is shown in Figure 7 . The particle size distributions for the experiments are given in Appendix $A$.

\subsubsection{FLOW THROUGH SAMPLE CAPILLARY APPARATUS}

As mentioned in section 4.3, the penetration of radio-aerosols in the sample capillary was calculated by using filter papers in the inlet and outlet capillaries to collect the radio-aerosol particles. Since a filter was at the opening of the inlet capillary and a filter was placed at the exit of the sample capillary, the flows through both capillaries were not exactly the same. This flow rate difference affected the deposition of particles inside the capillaries which subsequently influenced the penetration through the sample capillary. It was not possible to determine the flow through the individual capillaries, therefore, it was not possible to make a correction for flow rates. The flow rates through the capillaries were determined to be less than $5 \mathrm{ml} \mathrm{min}^{-1}$. The flow through the capillaries without the filter attachments was in the laminar regime, and was checked by calculating the Reynolds's number. This was calculated by assuming the flow rate was $5 \mathrm{ml} \mathrm{min}^{-1}$. For a laminar flow, the Reynolds number should be equal to or less than 2300 .

$$
\text { Reynolds \# }=\frac{\rho V d}{\mu}
$$




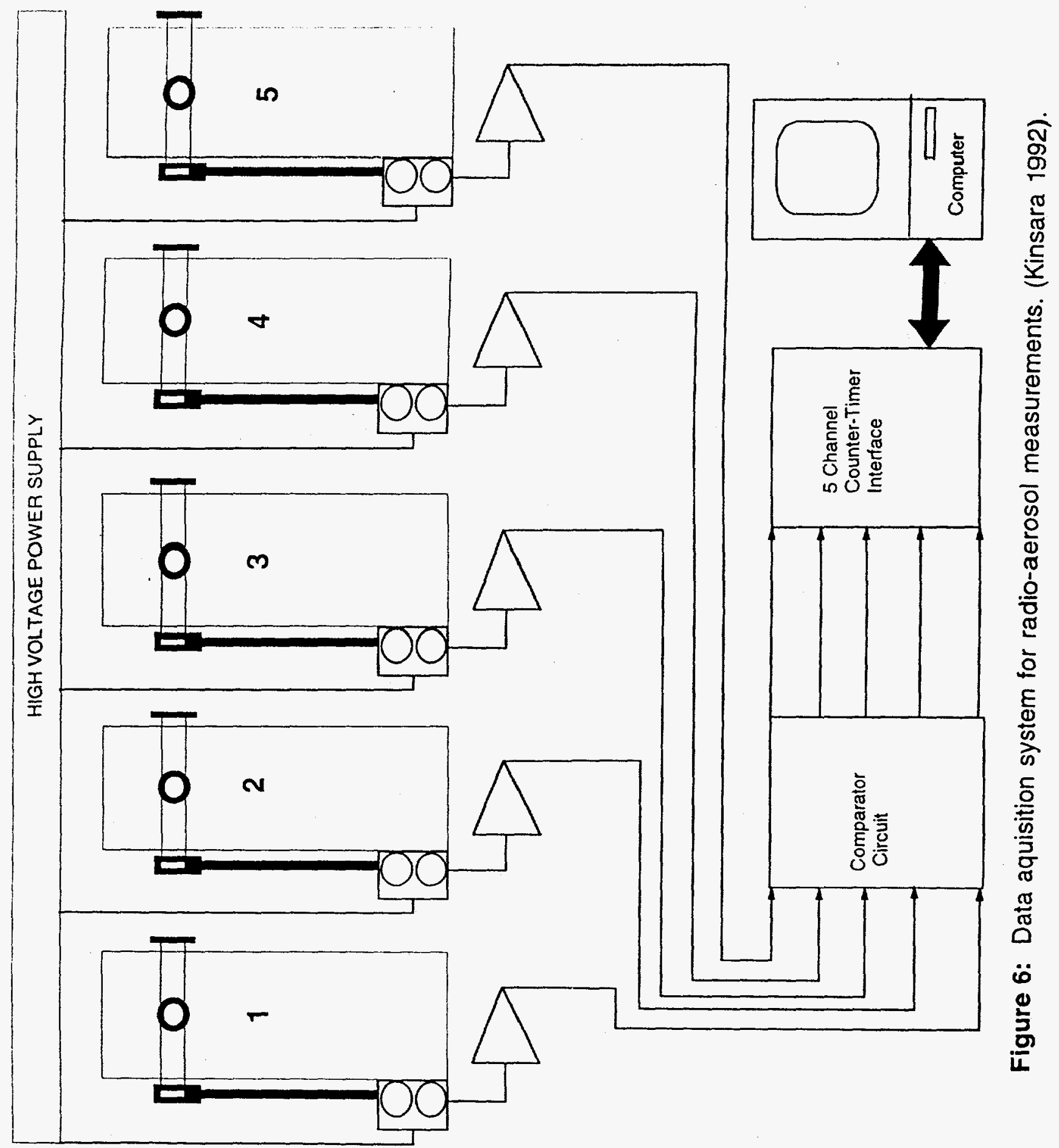




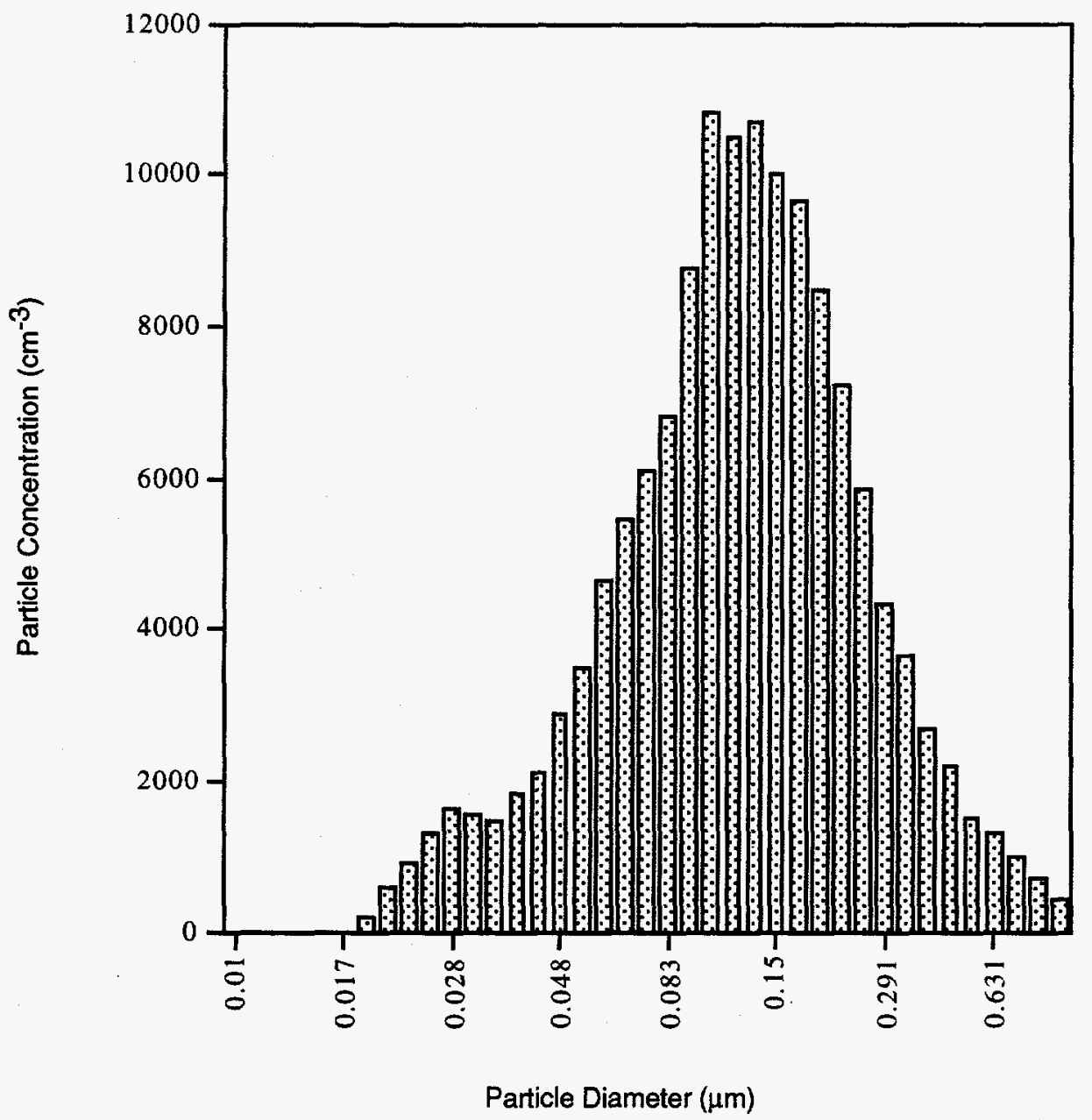

Figure 7: Typical particle size distribution determined by a TSI DMPS system for $0.1 \mu \mathrm{m}$ diameter aerosol particles. 
The diameter of the capillary, $d$, used in this experiment was $250 \mu \mathrm{m}$. Therefore, the velocity through the capillary was

$$
V=\frac{Q}{A}=\frac{5 \mathrm{ml} \mathrm{min}^{-1}}{\frac{\pi}{4} \mathrm{~d}^{2}}
$$

Using $\rho$ and $\mu$ for air, the Reynolds number

$$
\text { Reynold's \# }=\frac{1.205 \mathrm{~kg} \mathrm{~m}^{-3} 1.69 \mathrm{~ms}^{-1} 250 \mathrm{um}}{1.8 \mathrm{E}-5 \mathrm{~kg} \mathrm{~m}^{-1} \mathrm{~s}^{-1}} \approx 30
$$

Therefore, the flow through the capillary was well within the laminar regime.

\subsection{RADON DAUGHTERS}

An important assumption made throughout the experiment was the equilibrium state of the radio-aerosol in the main chamber. It was assumed that the reference and sample capillaries were exposed to the radio-aerosol in the main chamber at the same exact time and for the same duration. Based on this assumption, the relative concentrations between the radon daughters are considered to be the same for each filter. Therefore, the difference in radioaerosol counts associated with the reference and sample capillaries strictly depended upon radio-aerosol penetration. 


\section{CHAPTER 5 \\ THE EXPERIMENT}

The objective of this experiment was to study the effects of humidity on radio-aerosol penetration through ultrafine capillaries. The main chamber was purged for at least $12 \mathrm{~h}$ prior to testing to remove impurities from the chamber. This purging process generated a clean, particle-free environment. This environmental condition was checked with a condensation nucleus counter to ensure that the particle concentration was less than 1 particle $\mathrm{cm}^{-3}$ in the main chamber.

Aerosols were generated from a particulate solution using an atomizer with an air flow rate of $1.9 \mathrm{~L} \mathrm{~min}^{-1}$. The particles were mixed at a volumetric concentration of 1 part to 1000 parts distilled water. Compressed air entered the radon generator (Pylon Model $\mathrm{RN}-1025$ ) at a flow rate of $1.0 \mathrm{~L} \mathrm{~min}^{-1}$. This air stream supplied radon gas to the system with an activity of $69 \mathrm{~Bq} \mathrm{~L}-1$. The radon gas and the aerosol were mixed in the mixing chamber, as previously shown Figure 2.

This radio-aerosol was directed through a humidifier and then into the main chamber for at least four hours prior to testing. This four hour period allowed an equilibrium state of radio-aerosol to develop in the chamber. The main chamber was pressurized to $220 \mathrm{kPa}$ gage. Once the desired environmental conditions in the main chamber were established, the inlet and outlet capillaries were connected to the main chamber for a specific sampling time. After the sample time expired, the capillaries were simultaneously disconnected from the main chamber. The exposed filters were removed from the capillary apparatus. The filters were placed in the $\mathrm{ZnS}$ alpha detectors and were counted for 14 minutes. The counts were then corrected for the detector 
efficiency. The approximate number of radioactive decays were calculated. These results were used to calculate the penetration for the sample capillary. 


\section{CHAPTER 6}

\section{RESULTS}

A number of tests were conducted at different relative humidities and time intervals. The experiments were conducted at relative humidities of $20 \%, 50 \%$ and $80 \%$, with sampling times of 20,40 , and $60 \mathrm{~min}$. The potential for capillaries to be clogged during testing existed. This potential plugging of capillaries was determined by performing additional tests at different sampling times. These additional time tests were made with sampling times ranging from 20 to $180 \mathrm{~min}$ at a relative humidity of $50 \%$.

The resulting penetration values are presented graphically in the following figures. Figures $8 \mathrm{a}, 9 \mathrm{a}, 10 \mathrm{a}$, and 11a show the penetrations calculated for specific sampling times and humidities. Figures $8 b, 9 b, 10 b$, and $11 \mathrm{~b}$ show the penetrations with their corresponding error bars. The data were presented in this manner to show penetration trends. All recorded data are listed in Appendix A. Appendix B contains sample calculations for penetration and error. Values for penetration and error are listed in Appendix C. 


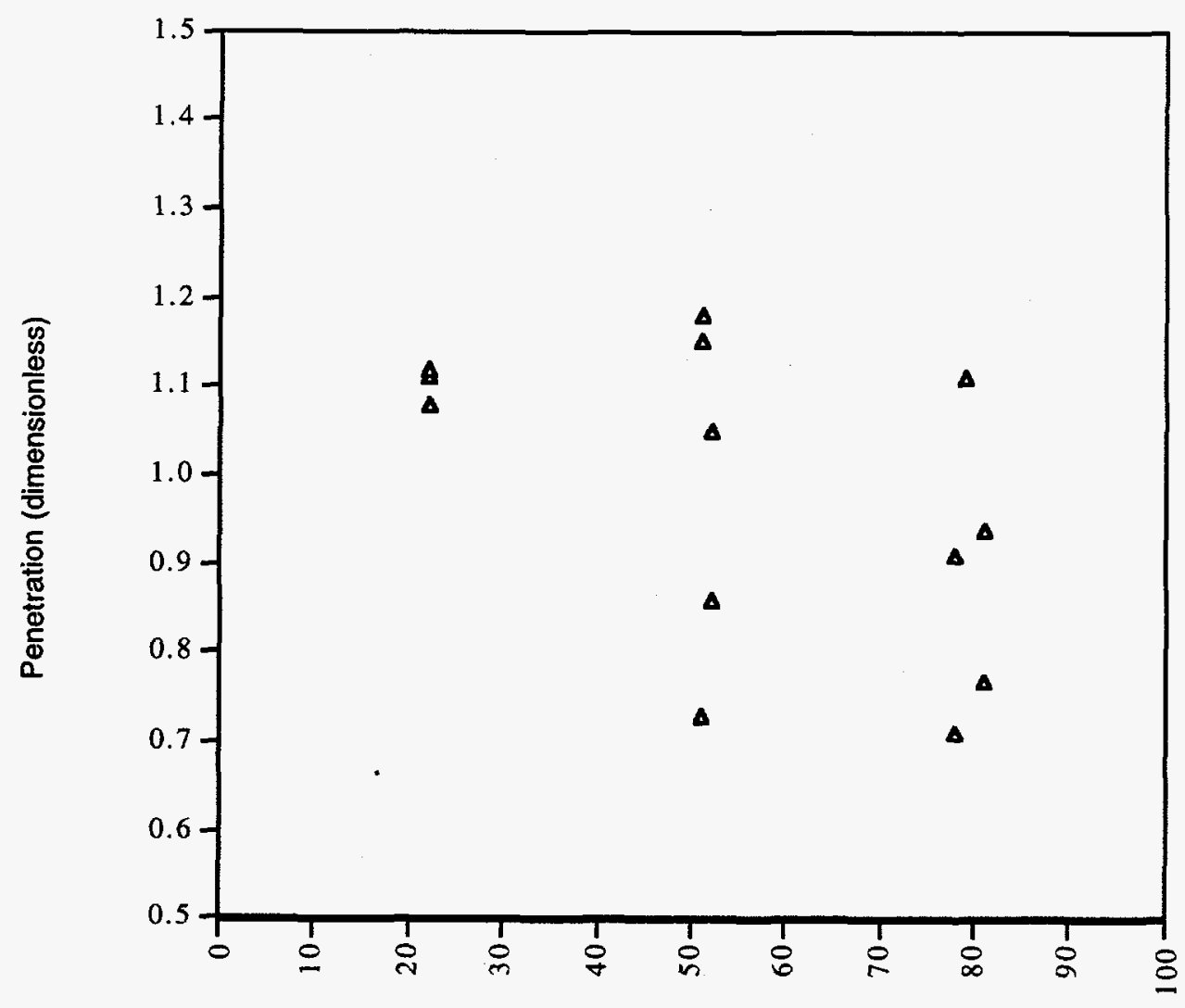

Relative Humidity (\%)

Figure 8a: Radio-aerosol penetration dependence on relative humidity for radio-aerosol particles $(0.1 \mu \mathrm{m}$ dia.) passing through an ultrafine capillary (250 $\mu \mathrm{m} \mathrm{dia.)} \mathrm{for} 20 \mathrm{~min}$. 


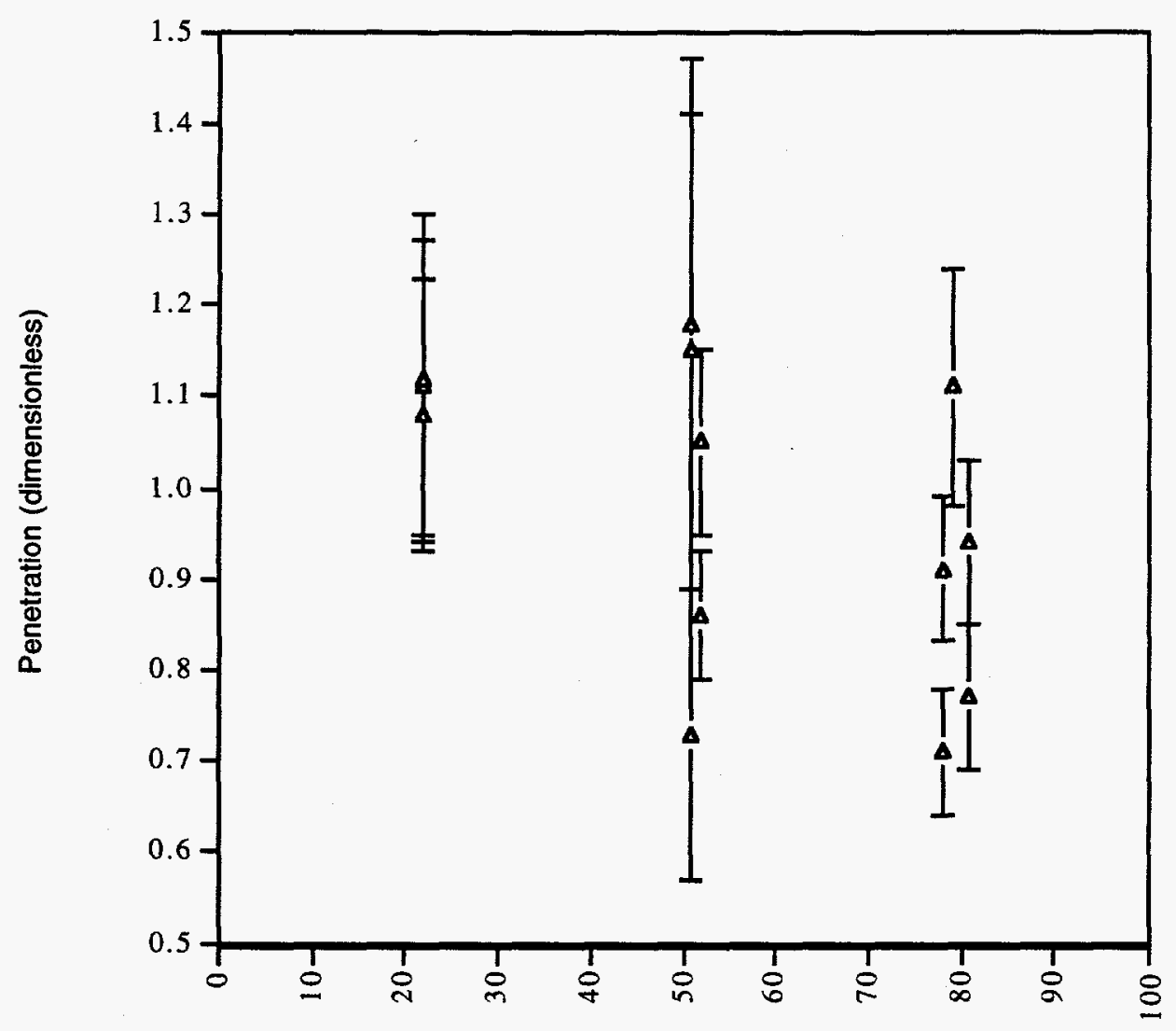

Relative Humidity (\%)

Figure 8b: Radio-aerosol penetration dependence on relative humidity with error bars for radio-aerosol particles $(0.1 \mu \mathrm{m}$ dia.) passing through an ultrafine capillary $(250 \mu \mathrm{m}$ dia.) for $20 \mathrm{~min}$. 


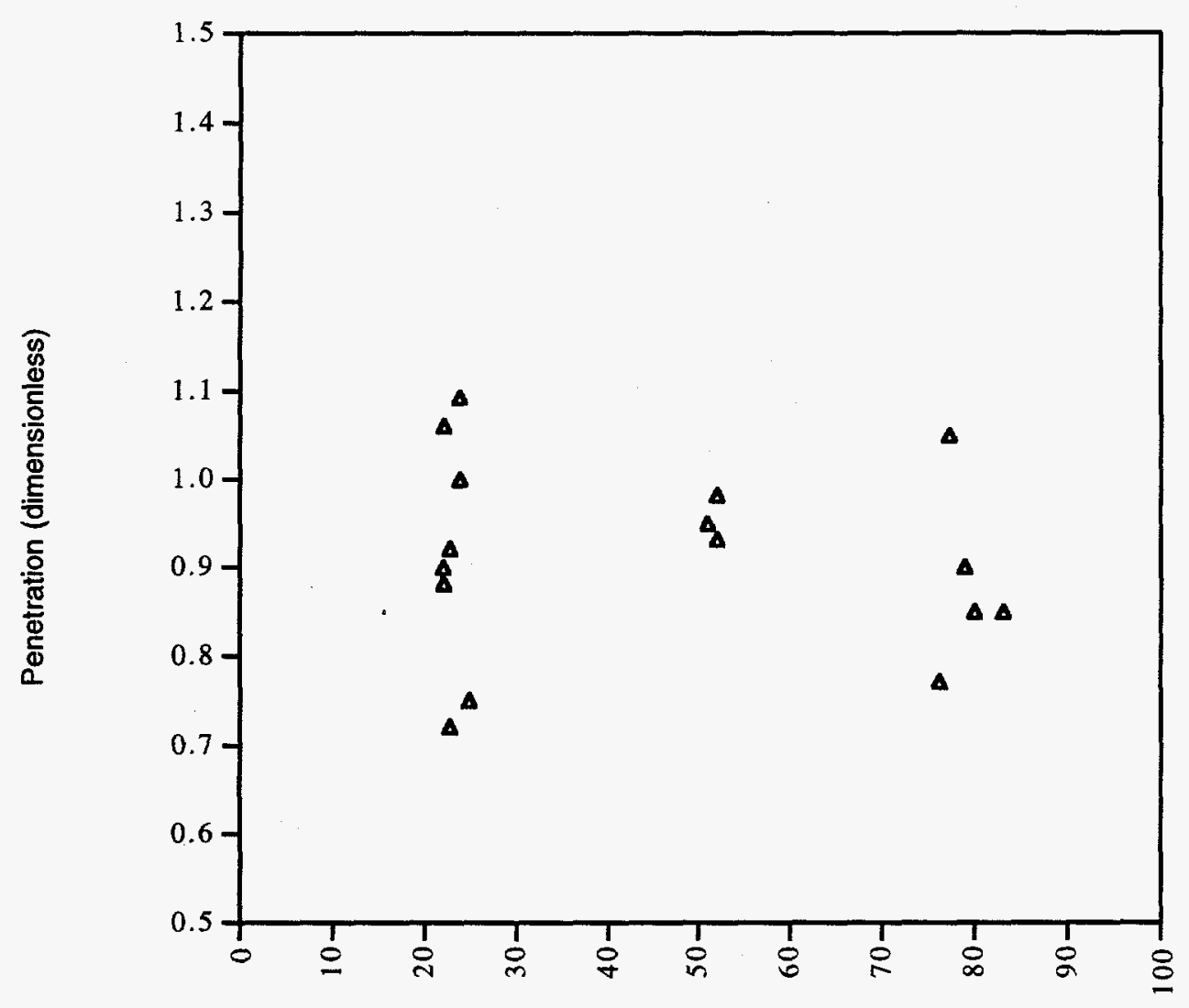

Relative Humidity (\%)

Figure 9a: Radio-aerosol penetration dependence on relative humidity for radio-aerosol particles $(0.1 \mu \mathrm{m}$ dia.) passing through an ultrafine capillary (250 $\mu \mathrm{m} \mathrm{dia.)}$ for $40 \mathrm{~min}$. 


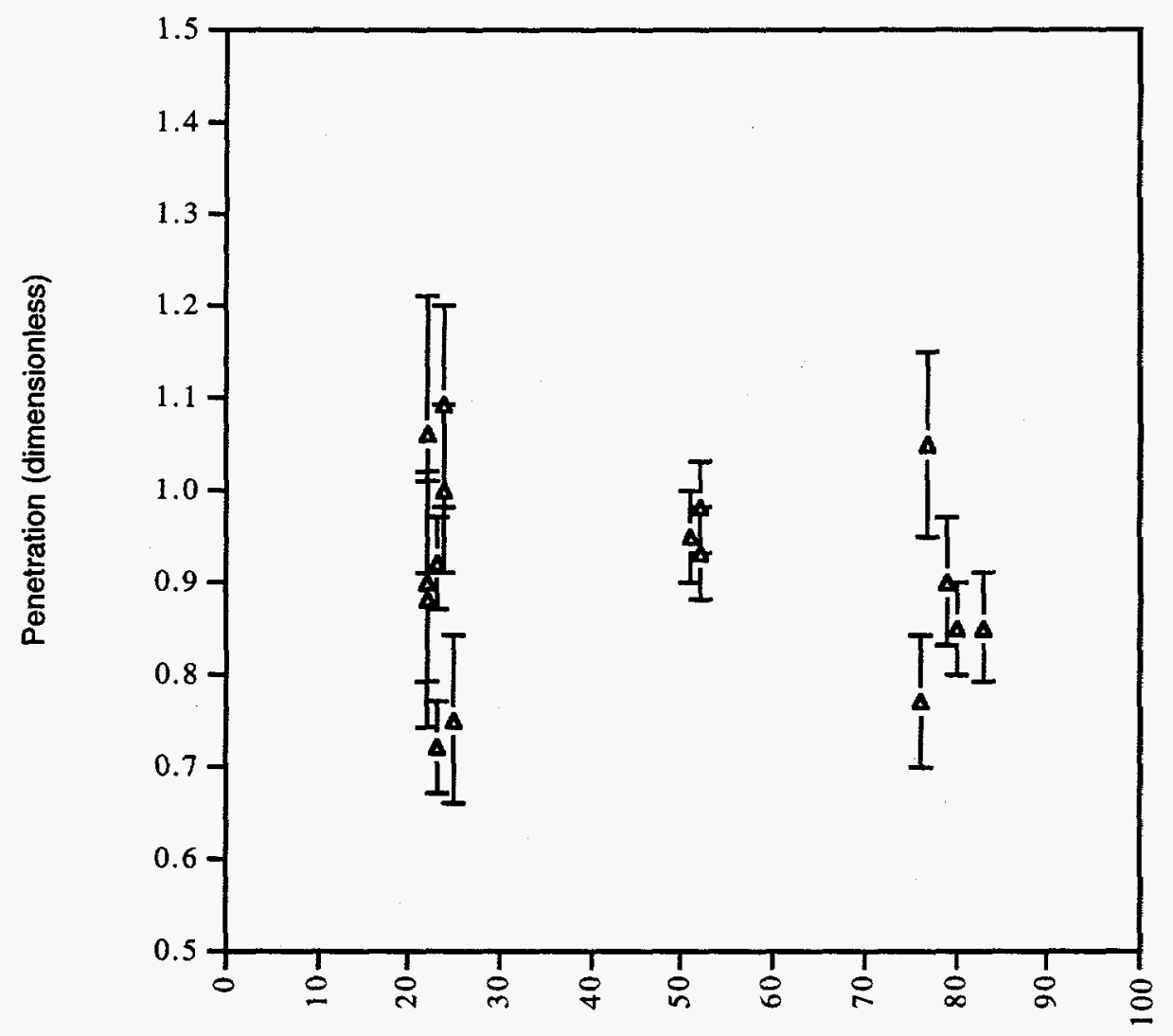

Relative Humidity (\%)

Figure 9b: Radio-aerosol penetration dependence on relative humidity with error bars for radio-aerosol particles $(0.1 \mu \mathrm{m}$ dia.) passing through an ultrafine capillary $(250 \mu \mathrm{m} \mathrm{dia}$.) for $40 \mathrm{~min}$. 


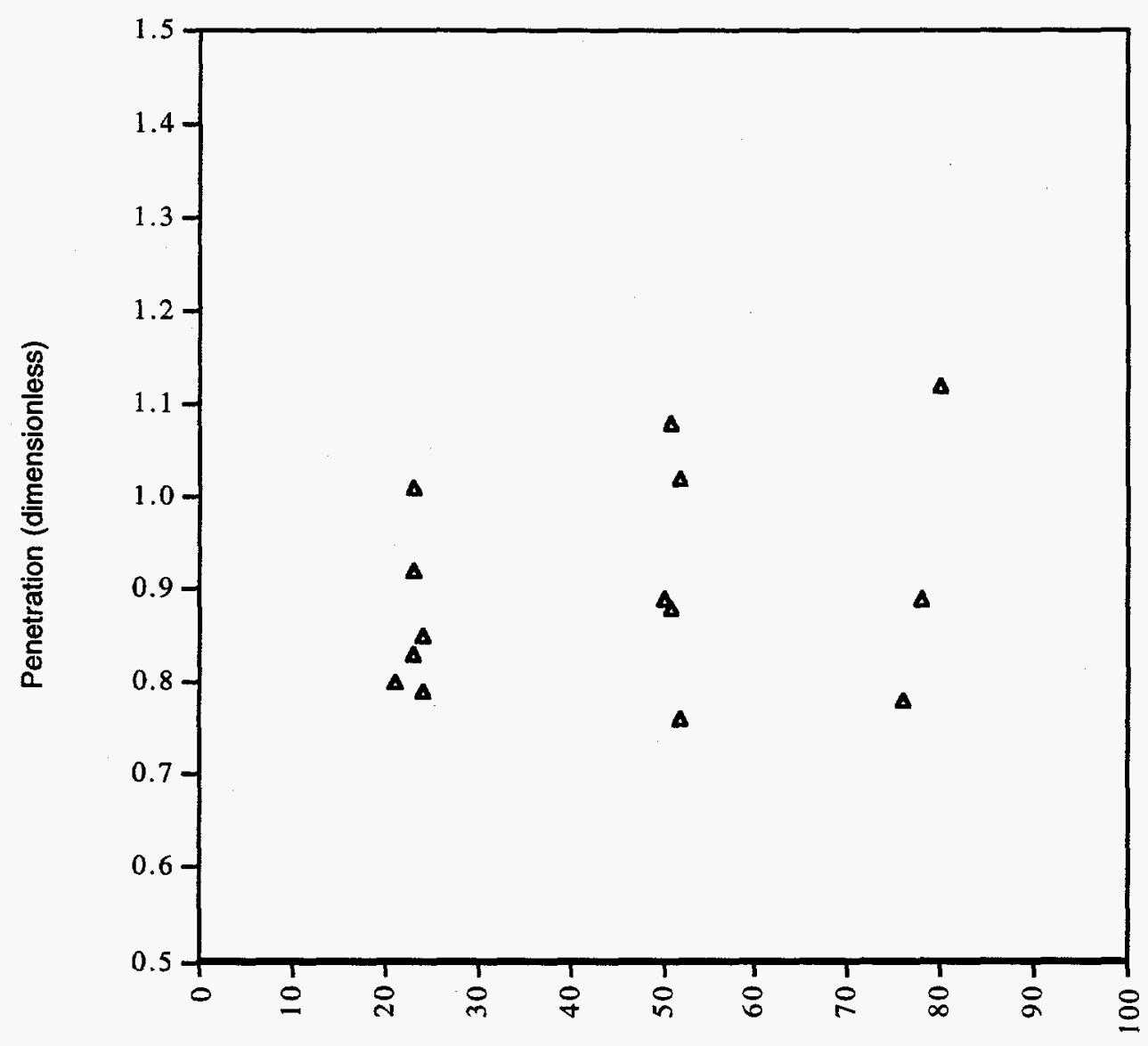

Relative Humidity (\%)

Figure 10a: Radio-aerosol penetration dependence on relative humidity for radio-aerosol particles $(0.1 \mu \mathrm{m}$ dia.) passing through an ultrafine capillary (250 $\mu \mathrm{m} \mathrm{dia.)} \mathrm{for} 60 \mathrm{~min}$. 


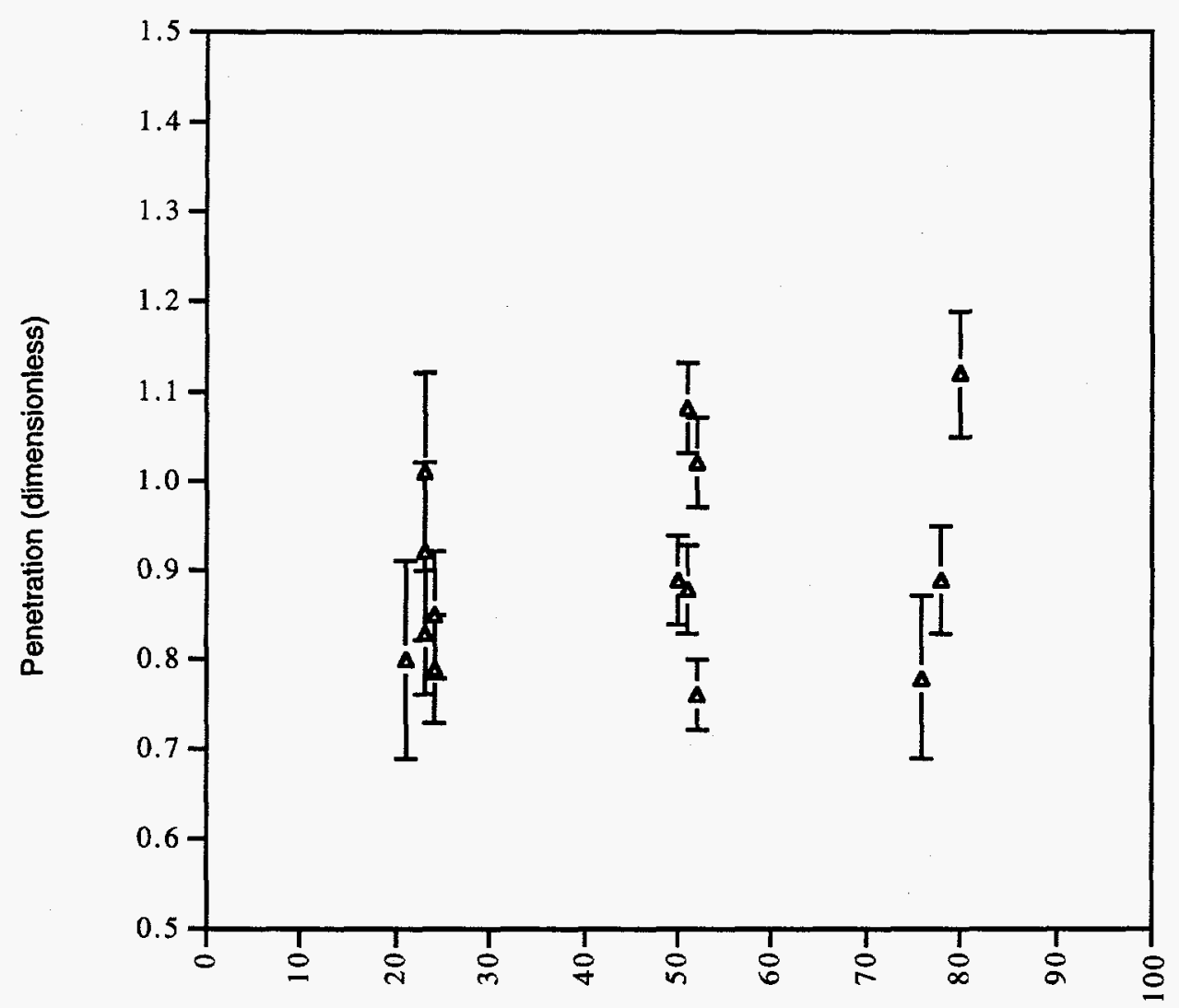

Relative Humidity (\%)

Figure 10b: Radio-aerosol penetration dependence on relative humidity with error bars for radio-aerosol particles $(0.1 \mu \mathrm{m}$ dia.) passing through an ultrafine capillary $(250 \mu \mathrm{m} \mathrm{dia}$.) for $60 \mathrm{~min}$. 


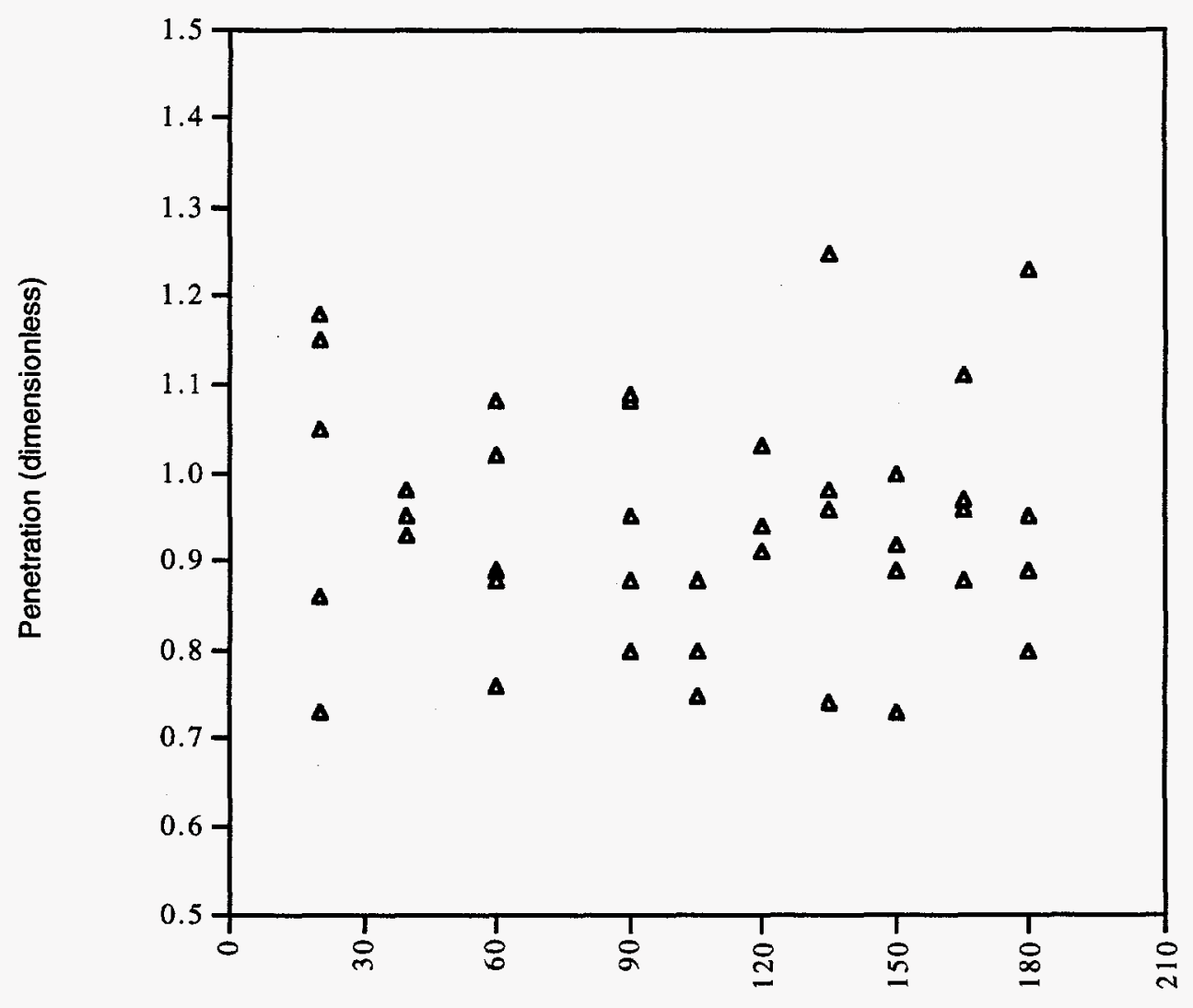

Sampling Time (minutes)

Figure 11a: Radio-aerosol penetration dependence on time for radio-aerosol particles $(0.1 \mu \mathrm{m}$ dia.) passing through an ultrafine capillary $(250 \mu \mathrm{m}$ dia.) at a relative humidity of $50 \%$. 


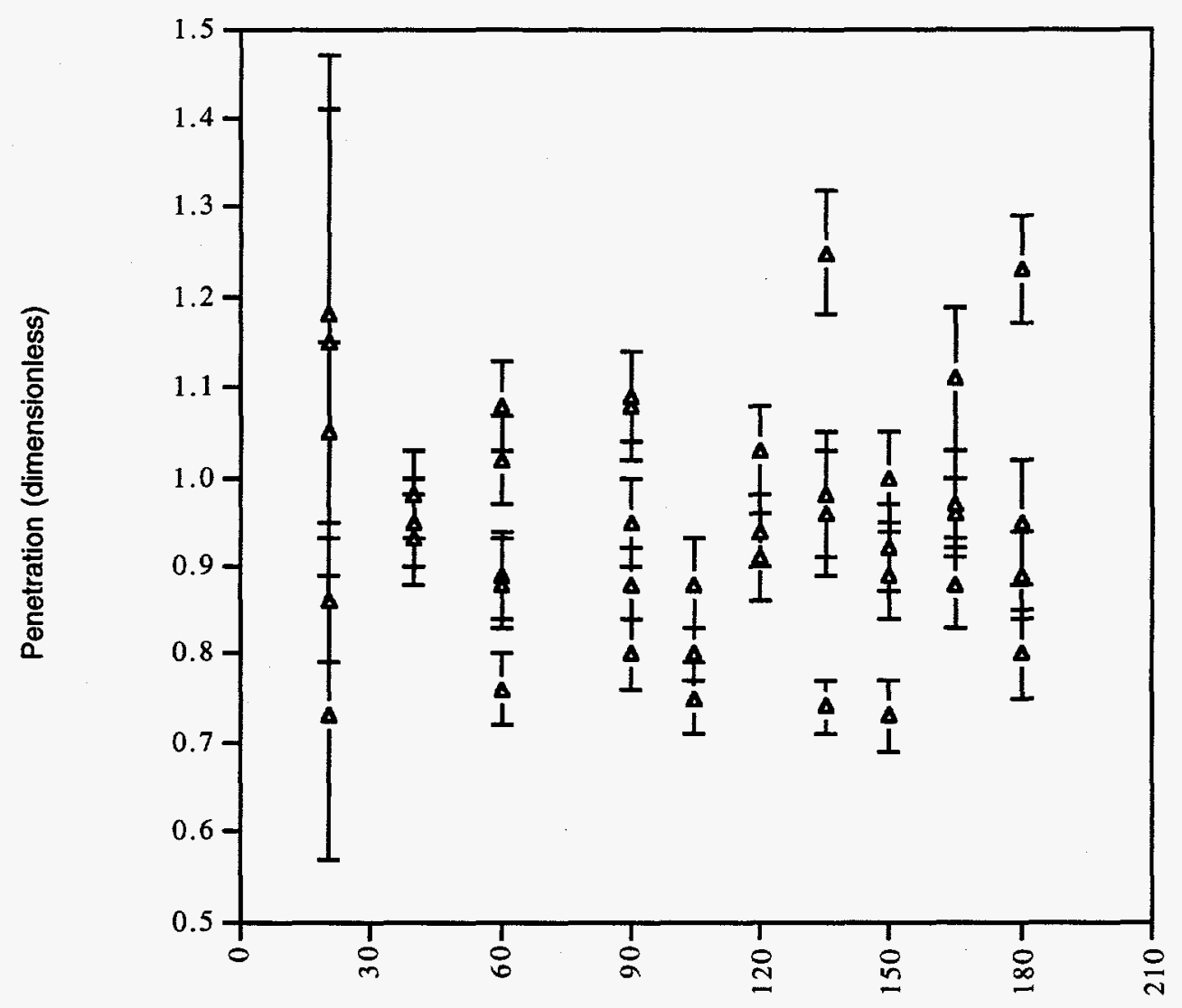

Sampling Time (minutes)

Figure 11b: Radio-aerosol penetration dependence on time with error bars for radio-aerosol particles $(0.1 \mu \mathrm{m}$ dia.) passing through an ultrafine capillary $(250 \mu \mathrm{m}$ dia.) at a relative humidity of $50 \%$. 


\section{CHAPTER 7}

\section{DATA ANALYSIS}

Since the data from these tests varied so significantly, the identification of radio-aerosol penetration trends was inconclusive. As observed in Figures $8 \mathrm{a}$, $9 \mathrm{a}$, and $10 \mathrm{a}$, the wide spread of data made it impossible to determine the effect of relative humidity on penetration. Also, there was not an obvious penetration characteristic dependent on time for various samples at $50 \%$ humidity, as shown in Figures $11 \mathrm{a}$ and $11 \mathrm{~b}$. The standard deviations for the penetration data points are represented graphically in Figures $8 \mathrm{~b}, 9 \mathrm{~b}, 10 \mathrm{~b}$, and $11 \mathrm{~b}$.

The standard deviation for all penetration data ranged from $3 \%$ to $30 \%$. The standard deviations are listed in Appendix C. Standard deviations for each data point were determined by using propagation of error calculations and standard error calculations for counts of radioactivity as described by Tsoulfanidis (1983) in Measurement and Detection of Radiation. The wide variance in the standard deviations added to the difficulty of determining the humidity effect on radioaerosol penetration.

Some factors that might have contributed to the scattering of the data are discussed below. The particle size of the aerosol has an inherent error associated with its generation. The size distribution might have been affected by the presence of radon daughters and water vapor. The particle size distribution in the chamber after the introduction of radon and moisture was never determined. During preparation of the ultrafine capillaries, the orifice geometries of the sample capillaries were altered. This alteration occurred when the capillaries were being cut to their proper length. Each capillary was visually inspected to minimize this problem. The aerosol concentration in the chamber was approximately $10^{4}$ particles $\mathrm{cm}^{-3}$ throughout the experiment. 
However, the aerosol concentration was not monitored during testing which may affect the capillary penetration even though Clement (1994) had suggested differently. The filters in the capillaries were not flushed against the vacuum connections and capillary orifices, therefore, it can be assumed that some particle loss occurred in the vacuum connections and in the filter holders. The exhaust flow was not monitored throughout the experiment. Consequently, it is possible that the exhaust flow may have been irregular throughout the testing, thus, affecting the flow through the capillaries. Errors resulting from different flows in the inlet and outlet capillaries could not be adjusted as discussed in section 4.5.4. As mentioned in section 4.6, the relative proportion of radon daughters on each filter may have not been equally distributed resulting in a penetration calculation that was not accurate. 


\section{CHAPTER 8}

\section{CONCLUSION AND RECOMMENDATIONS}

The results of this study suggest that a better control of the experimental parameters is needed to obtain more accurate data from experiments associated with radio-aerosol penetration in the presence of moisture. Also, any literature that discussed capillary flow dependence on humidity was not available. Therefore, a comparison of the results obtained in this study could not be made. Nel (1994) performed experiments on the effect of humidity on radio-aerosol deposition, and his results also varied greatly and were inconclusive. The experimental parameters that may have contributed to the wide variance of data, include aerosol flow, radio-aerosol generation, capillary characteristics, humidity control, and radiation measurements. It was the uncertainty of these parameters that contributed to the poor data which made conclusive deductions about radio-aerosol penetration dependence on humidity difficult. Linear fits to the data were made, however, the data correlations were very poor making it impossible to identify trends.

The following experimental improvements are suggested for future studies that may help to draw a conclusion regarding the effects of humidity on radio-aerosol flow. Errors in the data could have been reduced by increasing the radon concentration. The increased counts would have statistically reduced the error associated with the counts of radioactivity. It may be noted Nel (1994) also reported a similar observation. Using capillaries that did not require modifications would also minimize geometric dependency on capillary flow due to irregularities. Particle loss could also be minimized by using filter holders that are flush with the capillary orifices. A variety of fundamental studies should be conducted to verify that proper experimental techniques were being used 
prior to making more complicated studies. For example, simple studies addressing radio-aerosol flow at various aerosol concentrations, particle diameters, capillary diameters and capillary lengths should be conducted prior to making more complicated studies. 


\section{REFERENCES}

1) Aritomi, M., Asano, R., Li, N. and Asano, H. "Evaluation Method of Gas Leakage Rate from Transportation Casks of Radioactive Material..." Journal of Nuclear Science and Technology 31[4] (1994): 264-273.

2) Clement, C.F. "Aerosol Penetration through Capillaries and Leaks: Theory." J. Aerosol Sci. 26[3] (1995): 369-385.

3) Cochran, R. G. and Tsoulfanidis, N. The Nuclear Fuel Cycle: Analysis and Management. Illinois: American Nuclear Society, 1990.

4) Hinds, W. C. Aerosol Technology Properties. Behavior. and Measurement of Airborne Particles. New York: John Wiley \& Sons Inc, 1982.

5) Kinsara, A.A. "Deposition of the Radon Daughter Po-218 in a Lung Bifurcation Model." Diss. University of Missouri-Columbia. Nuclear Engineering Department, 1992.

6) Mitchell, J.P., Edwards, R.T. and Ball, M.H.E. "The Penetration of Aerosols through Fine Capillaries." RAMTRANS (Nuclear Technology) 1[2] (1990): 101-116.

7) Morewitz, H.A. "Leakage of Aerosols from Containment Buildings." Health Physics 42[2] (1982): 195-207.

8) Morton, D.A. and Mitchell, J.P. "Aerosol Penetration through Capillaries and Leaks: Experimental Studies on the Influence of Pressure." $\underline{\text { J. Aerosol }}$ Sci. 26[3] (1995): 353-367.

9) Nel, M. "Measurements of the Effect of Humidity on the Deposition of Po-218 in a Lung Model." M.S. Thesis. University of Missouri-Columbia. Nuclear Engineering Department, 1994.

10) Stopford, P.J. and Williams, M.G. "The Modelling of Aerosol Sampling by Fine Capillaries and Small Orifices." AEA Technology D\&R 0158 (1992).

11) Stopford, P.J. and Williams, M.G. "The Modelling of Aerosol Deposition in Ultrafine Capillaries." AEATechnology D\&R 0377 (1992).

12) Sutter, S.L., Johnston, J.W., Owzarski, P.C., Mishima, J. and Schwendiman, L.C. "Depleted Uranium Dioxide Powder Flow through Very Small Openings." Nuclear Technology 52 (1981).

13) Todreas, N.E. and Kazimi, M.S. NUCLEAR SYSTEMS I ThermalHydraulic Fundamentals. New York: Hemisphere Publishing, 1990. 
14) Tsoulfanidis, N. Measurement and Detection of Radiation. New York: Hemisphere Publishing, 1983.

15) Van de Vate, J.F. "Safety Containment Buildings as Barriers Against Particulate Radioactivity Release Under Accident Conditions." Nuclear Technology 81 (1988).

16) White, F.M. Fluid Mechanics 3rd Edition. New Jersey: McGraw-Hill Inc, 1994.

17) Williams, M.M.R. and Loyalka, S.K. Aerosol Science: Theory and Practice. New York: Pergamon Press, 1991.

18) Williams, M.M.R. "Particle Deposition and Plugging in Tubes and Cracks ..." Progress in Nuclear Energy 28[1] (1994): 1-60.

19) Wyman, H.A. "Convective-Diffusive Deposition of Radon in Curved Capillaries." University of Missouri-Columbia. Particulate Systems Research Center, 1995. 


\author{
APPENDIX A: \\ RECORDED DATA AND PARTICLE SIZE DISTRIBUTIONS
}


Table A.1: Recorded data set \#1

\begin{tabular}{||c|c|c|c|c|c||}
\hline $\begin{array}{c}\text { Time } \\
(\mathrm{min})\end{array}$ & $\begin{array}{c}\text { Humidity } \\
(\%)\end{array}$ & $\begin{array}{c}\text { Background } \\
\text { Counts for } \\
\text { Detector 2 } \\
\text { (Outlet) }\end{array}$ & $\begin{array}{c}\text { Background } \\
\text { Counts for } \\
\text { Detector 1 } \\
\text { (Inlet) }\end{array}$ & $\begin{array}{c}\text { Counts } \\
\text { for Outlet } \\
\text { Capillary }\end{array}$ & $\begin{array}{c}\text { Counts } \\
\text { for } \\
\text { Inlet } \\
\text { Capillary }\end{array}$ \\
\hline \hline 20 & 22 & 1 & 1 & 108 & 97 \\
\hline 20 & 22 & 1 & 1 & 107 & 99 \\
\hline 20 & 22 & 1 & 1 & 89 & 79 \\
\hline 40 & 22 & 1 & 1 & 126 & 139 \\
\hline 40 & 22 & 1 & 1 & 112 & 105 \\
\hline 40 & 22 & 1 & 1 & 80 & 90 \\
\hline 60 & 21 & 7 & 1 & 107 & 125 \\
\hline 60 & 23 & 2 & 3 & 162 & 176 \\
\hline 60 & 23 & 2 & 3 & 176 & 175 \\
\hline
\end{tabular}




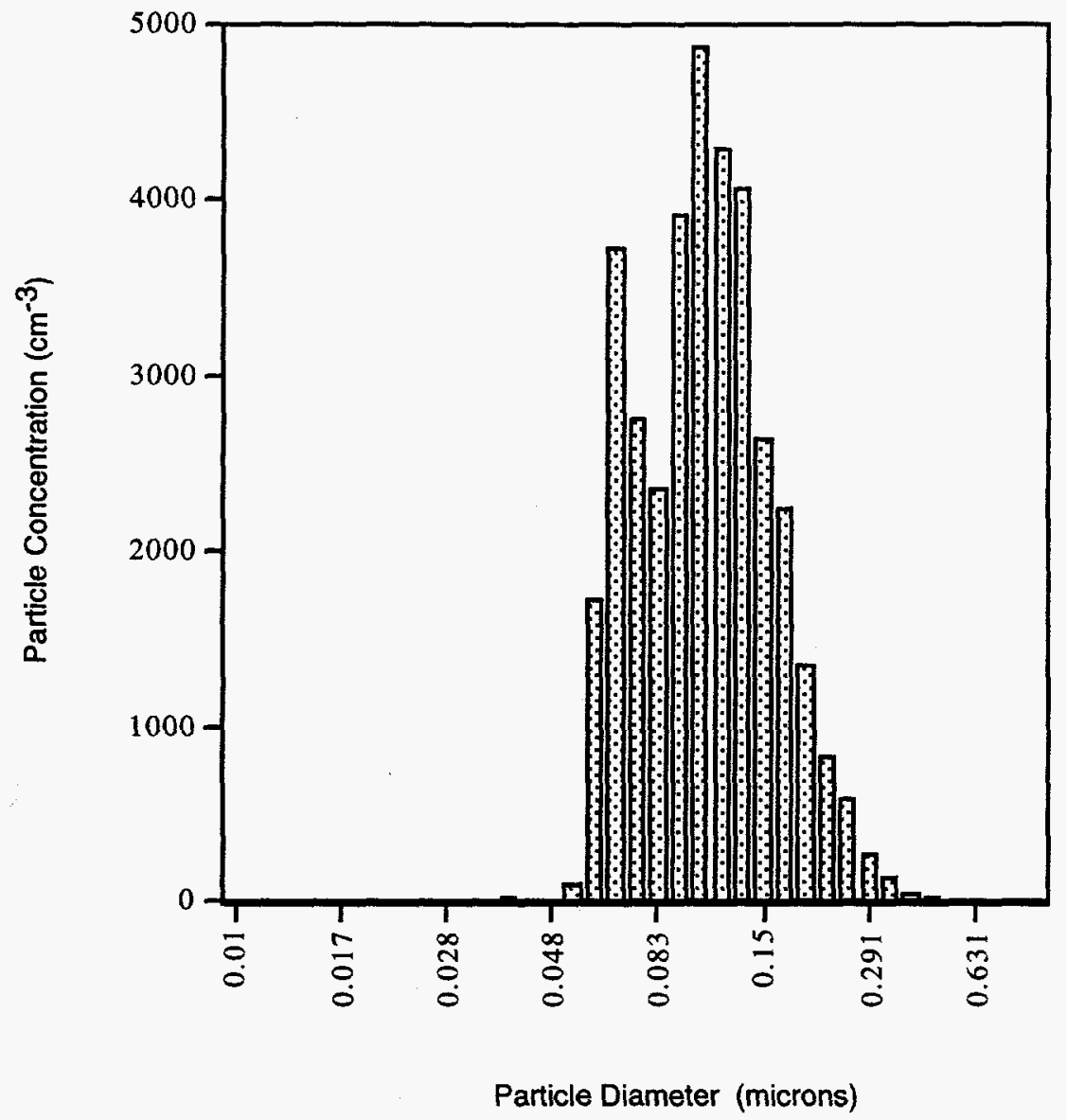

Figure A.1: Particle size distribution of 0.1 micron diameter particles for data in Table A.1 
Table A.2: Recorded data set \#2

\begin{tabular}{||c|c|c|c|c|c|}
\hline $\begin{array}{c}\text { Time } \\
(\mathrm{min})\end{array}$ & $\begin{array}{c}\text { Humidity } \\
(\%)\end{array}$ & $\begin{array}{c}\text { Background } \\
\text { Counts for } \\
\text { Detector 2 } \\
\text { (Outlet) }\end{array}$ & $\begin{array}{c}\text { Background } \\
\text { Counts for } \\
\text { Detector 1 } \\
\text { (Inlet) }\end{array}$ & $\begin{array}{c}\text { Counts } \\
\text { for Outlet } \\
\text { Capillary }\end{array}$ & $\begin{array}{c}\text { Counts } \\
\text { for } \\
\text { Inlet } \\
\text { Capillary }\end{array}$ \\
\hline \hline 20 & 51 & 3 & 0 & 49 & 40 \\
\hline 20 & 51 & 3 & 0 & 42 & 53 \\
\hline 20 & 51 & 3 & 0 & 42 & 33 \\
\hline 20 & 78 & 5 & 1 & 178 & 245 \\
\hline 20 & 79 & 5 & 1 & 172 & 151 \\
\hline 20 & 81 & 5 & 1 & 165 & 209 \\
\hline
\end{tabular}




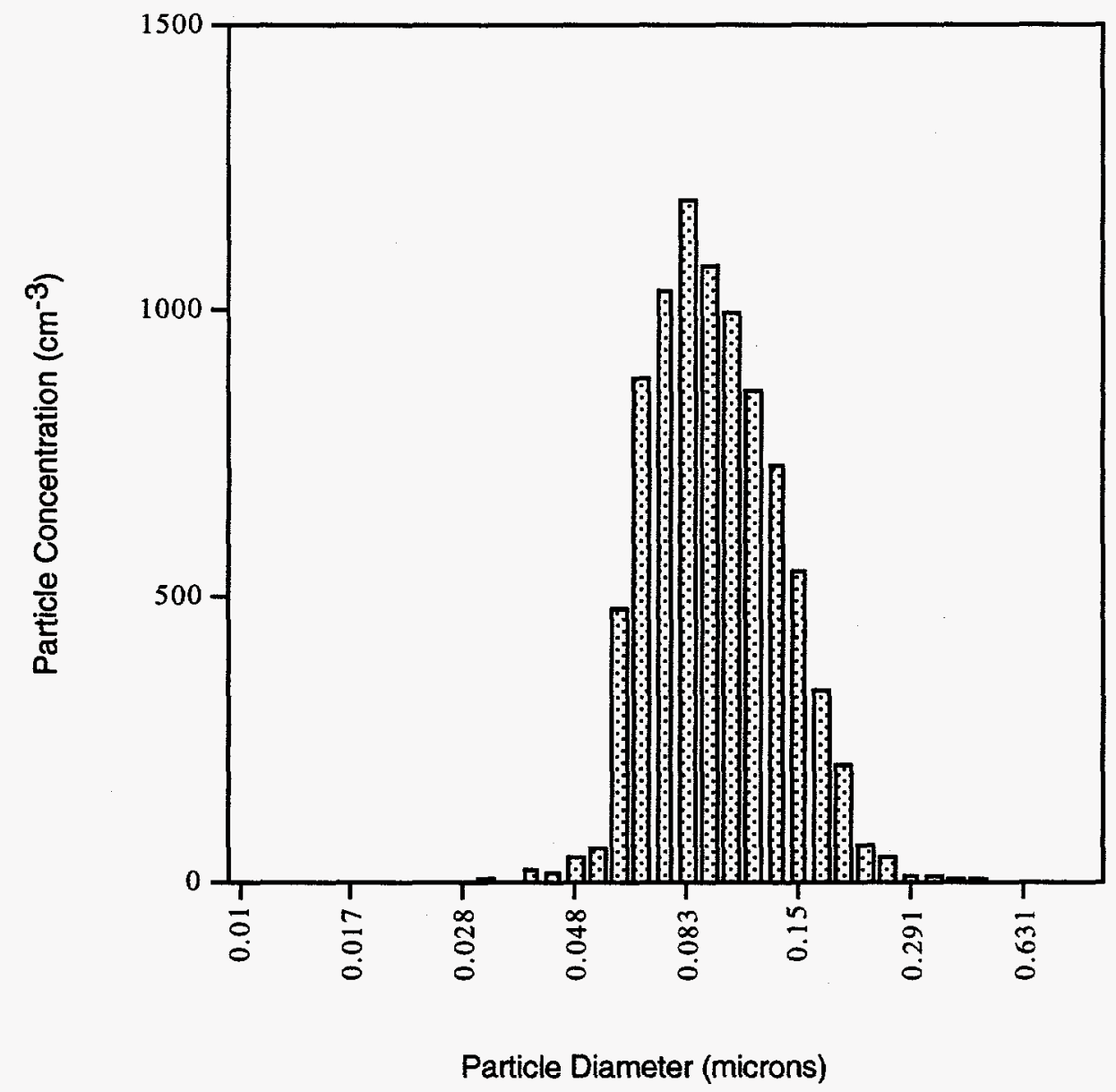

Figure A.2: Particle size distribution of 0.1 micron diameter particles for data in Table A.2 
Table A.3: Recorded data set \#3

\begin{tabular}{|c|c|c|c|c|c||}
\hline $\begin{array}{c}\text { Time } \\
(\mathrm{min})\end{array}$ & $\begin{array}{c}\text { Humidity } \\
(\%)\end{array}$ & $\begin{array}{c}\text { Background } \\
\text { Counts for } \\
\text { Detector 2 } \\
\text { (Outlet) }\end{array}$ & $\begin{array}{c}\text { Background } \\
\text { Counts for } \\
\text { Detector 1 } \\
\text { (Inlet) }\end{array}$ & $\begin{array}{c}\text { Counts } \\
\text { for Outlet } \\
\text { Capillary }\end{array}$ & $\begin{array}{c}\text { Counts } \\
\text { for } \\
\text { Inlet } \\
\text { Capillary }\end{array}$ \\
\hline \hline 40 & 76 & 2 & 1 & 212 & 273 \\
\hline 40 & 77 & 2 & 1 & 243 & 229 \\
\hline 60 & 88 & 2 & 1 & 110 & 114 \\
\hline 60 & 78 & 2 & 1 & 399 & 446 \\
\hline 60 & 76 & 2 & 1 & 129 & 164 \\
\hline 40 & 25 & 2 & 1 & 136 & 179 \\
\hline 40 & 24 & 2 & 1 & 229 & 208 \\
\hline 40 & 24 & 2 & 1 & 253 & 250 \\
\hline 60 & 24 & 2 & 1 & 312 & 365 \\
\hline 60 & 24 & 2 & 1 & 310 & 387 \\
\hline 60 & 23 & 2 & 1 & 276 & 330 \\
\hline 120 & 51 & 0 & 0 & 909 & 966 \\
\hline 120 & 50 & 0 & 0 & 908 & 878 \\
\hline 120 & 52 & 0 & 0 & 533 & 584 \\
\hline
\end{tabular}




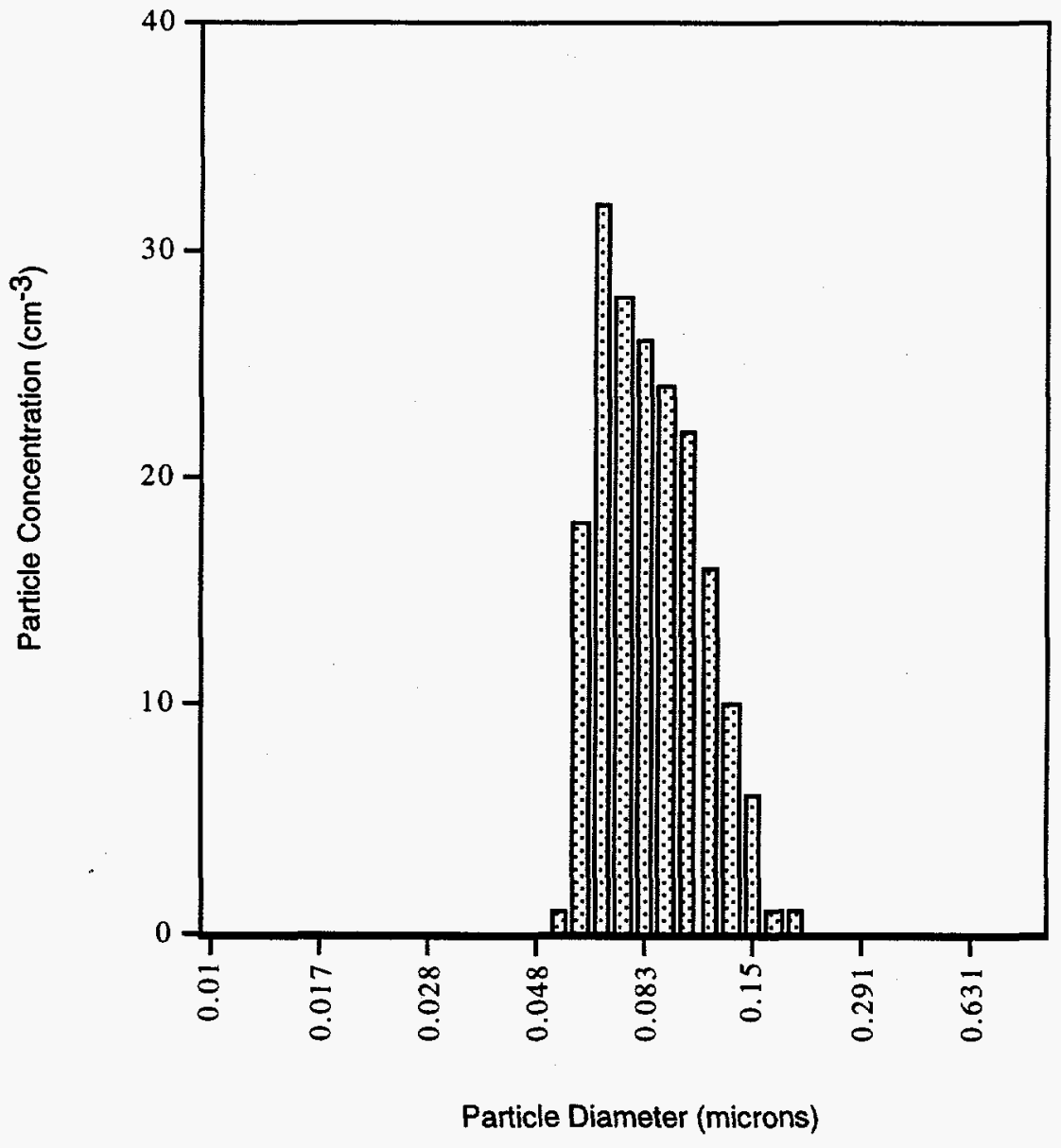

Figure A.3: Particle size distribution of 0.1 micron diameter particles for data in Table A.3 
Table A.4: Recorded data set \#4

\begin{tabular}{||c|c|c|c|c|c||}
\hline $\begin{array}{c}\text { Time } \\
(\mathrm{min})\end{array}$ & $\begin{array}{c}\text { Humidity } \\
(\%)\end{array}$ & $\begin{array}{c}\text { Background } \\
\text { Counts for } \\
\text { Detector 2 } \\
\text { (Outlet) }\end{array}$ & $\begin{array}{c}\text { Background } \\
\text { Counts for } \\
\text { Detector 1 } \\
\text { (Inlet) }\end{array}$ & $\begin{array}{c}\text { Counts } \\
\text { for Outlet } \\
\text { Capillary }\end{array}$ & $\begin{array}{c}\text { Counts } \\
\text { for } \\
\text { Inlet } \\
\text { Capillary }\end{array}$ \\
\hline \hline 180 & 52 & 1 & 0 & 860 & 697 \\
\hline 180 & 51 & 1 & 0 & 522 & 583 \\
\hline 40 & 52 & 0 & 2 & 816 & 878 \\
\hline 40 & 51 & 0 & 2 & 808 & 848 \\
\hline 40 & 52 & 0 & 2 & 689 & 702 \\
\hline 60 & 52 & 0 & 2 & 821 & 807 \\
\hline 60 & 50 & 0 & 2 & 724 & 815 \\
\hline 60 & 51 & 0 & 2 & 941 & 866 \\
\hline 180 & 51 & 0 & 2 & 532 & 665 \\
\hline
\end{tabular}




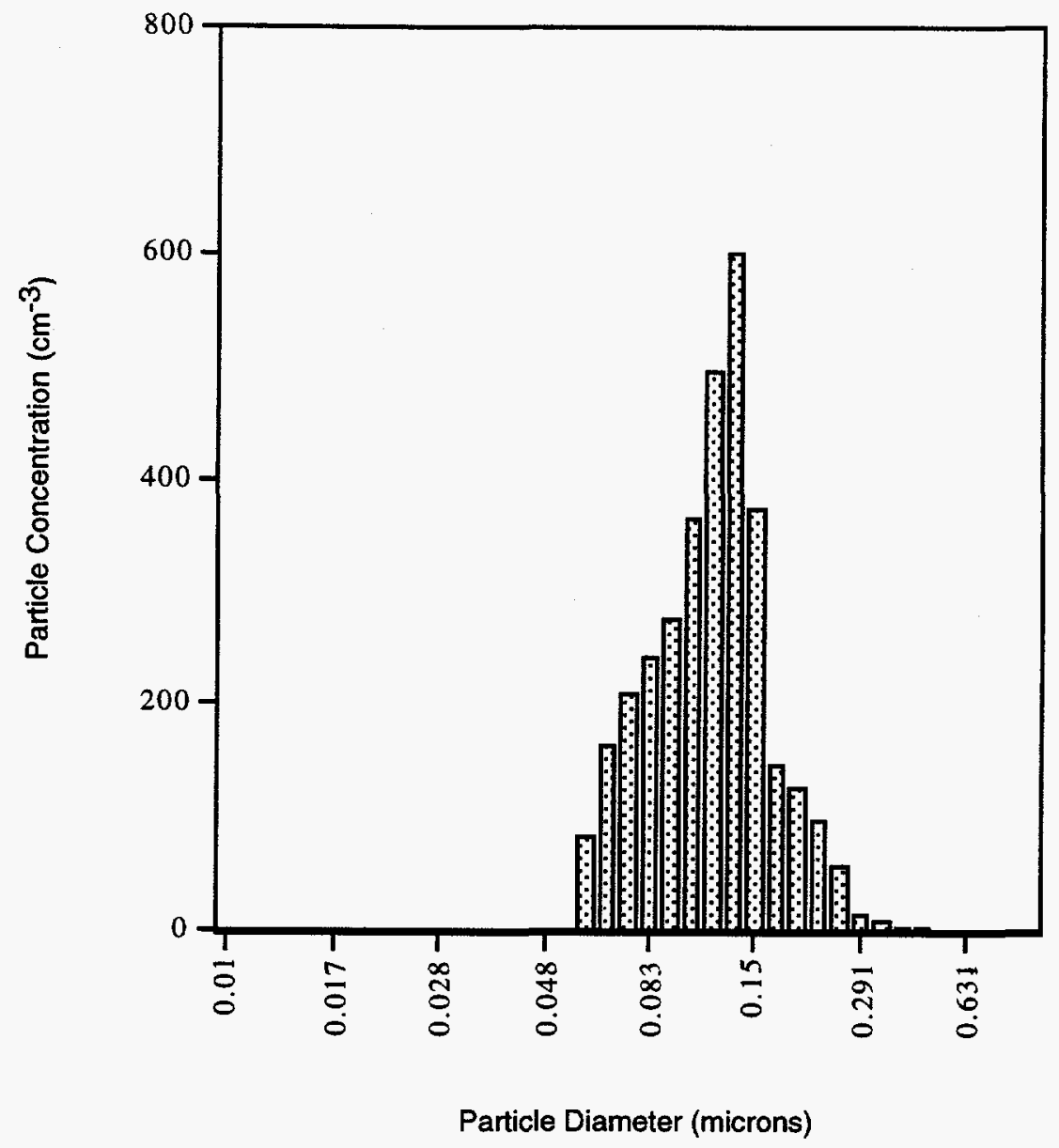

Figure A.4: Particle size distribution of 0.1 micron diameter particles for data in Table A.4. 
Table A.5: Recorded data set \#5

\begin{tabular}{||c|c|c|c|c|c||}
\hline \hline $\begin{array}{c}\text { Time } \\
(\mathrm{min})\end{array}$ & $\begin{array}{c}\text { Humidity } \\
(\%)\end{array}$ & $\begin{array}{c}\text { Background } \\
\text { Counts for } \\
\text { Detector 2 } \\
\text { (Outlet) }\end{array}$ & $\begin{array}{c}\text { Background } \\
\text { Counts for } \\
\text { Detector 1 } \\
\text { (Inlet) }\end{array}$ & $\begin{array}{c}\text { Counts } \\
\text { for Outlet } \\
\text { Capillary }\end{array}$ & $\begin{array}{c}\text { Counts } \\
\text { for } \\
\text { Inlet } \\
\text { Capillary }\end{array}$ \\
\hline \hline 20 & 52 & 2 & 3 & 294 & 343 \\
\hline 60 & 52 & 0 & 1 & 745 & 979 \\
\hline 90 & 52 & 1 & 4 & 590 & 739 \\
\hline 90 & 52 & 1 & 4 & 777 & 887 \\
\hline 90 & 51 & 1 & 4 & 691 & 724 \\
\hline 150 & 51 & 2 & 3 & 549 & 748 \\
\hline 150 & 51 & 2 & 3 & 651 & 728 \\
\hline 150 & 51 & 0 & 1 & 660 & 714 \\
\hline
\end{tabular}




$$
\text { I }
$$


Table A.6: Recorded data set \#6

\begin{tabular}{||c|c|c|c|c|c||}
\hline $\begin{array}{c}\text { Time } \\
(\mathrm{min})\end{array}$ & $\begin{array}{c}\text { Humidity } \\
(\%)\end{array}$ & $\begin{array}{c}\text { Background } \\
\text { Counts for } \\
\text { Detector 2 } \\
\text { (Outlet) }\end{array}$ & $\begin{array}{c}\text { Background } \\
\text { Counts for } \\
\text { Detector 1 } \\
\text { (Inlet) }\end{array}$ & $\begin{array}{c}\text { Counts } \\
\text { for Outlet } \\
\text { Capillary }\end{array}$ & $\begin{array}{c}\text { Counts } \\
\text { for } \\
\text { Inlet } \\
\text { Capillary }\end{array}$ \\
\hline \hline 40 & 23 & 6 & 1 & 610 & 656 \\
\hline 40 & 23 & 6 & 1 & 331 & 449 \\
\hline 20 & 52 & 6 & 1 & 243 & 225 \\
\hline 60 & 51 & 6 & 1 & 579 & 646 \\
\hline 60 & 51 & 5 & 6 & 557 & 633 \\
\hline 90 & 52 & 2 & 1 & 613 & 565 \\
\hline 90 & 52 & 2 & 1 & 890 & 815 \\
\hline 105 & 51 & 4 & 2 & 244 & 737 \\
\hline 105 & 50 & 2 & 1 & 690 & 778 \\
\hline 105 & 52 & 4 & 2 & 559 & 735 \\
\hline 105 & 52 & 2 & 6 & 1071 & 1333 \\
\hline 120 & 50 & 6 & 1 & 212 & 555 \\
\hline 135 & 51 & 3 & 2 & 381 & 387 \\
\hline 135 & 51 & 5 & 6 & 717 & 574 \\
\hline 135 & 50 & 4 & 2 & 143 & 508 \\
\hline 180 & 51 & 5 & 6 & 414 & 436 \\
\hline
\end{tabular}




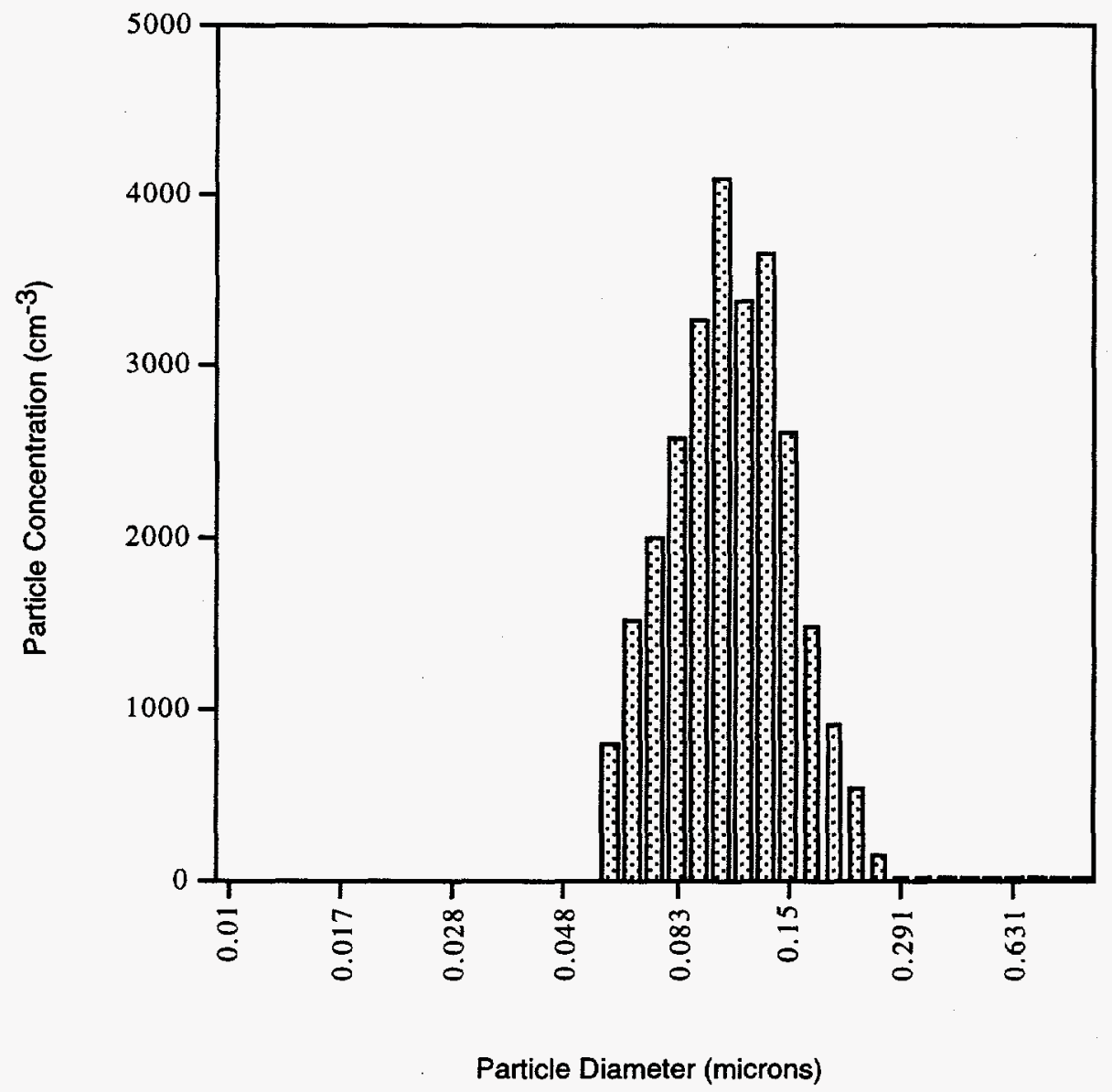

Figure A.6: Particle size distribution of 0.1 micron diameter particles for data in Table A.6. 
Table A.7: Recorded data set \#7

\begin{tabular}{||c|c|c|c|c|c||}
\hline $\begin{array}{c}\text { Time } \\
(\mathrm{min})\end{array}$ & $\begin{array}{c}\text { Humidity } \\
(\%)\end{array}$ & $\begin{array}{c}\text { Background } \\
\text { Counts for } \\
\text { Detector 2 } \\
\text { (Outlet) }\end{array}$ & $\begin{array}{c}\text { Background } \\
\text { Counts for } \\
\text { Detector 1 } \\
\text { (Inlet) }\end{array}$ & $\begin{array}{c}\text { Counts } \\
\text { for Outlet } \\
\text { Capillary }\end{array}$ & $\begin{array}{c}\text { Counts } \\
\text { for } \\
\text { Inlet } \\
\text { Capillary }\end{array}$ \\
\hline \hline 135 & 52 & 1 & 2 & 845 & 1137 \\
\hline 135 & 52 & 1 & 2 & 1037 & 711 \\
\hline 135 & 51 & 3 & 2 & 438 & 452 \\
\hline 165 & 50 & 1 & 2 & 1021 & 1063 \\
\hline 165 & 50 & 1 & 0 & 589 & 605 \\
\hline 165 & 52 & 1 & 0 & 421 & 376 \\
\hline 165 & 51 & 1 & 0 & 177 & 386 \\
\hline 165 & 50 & 3 & 2 & 524 & 595 \\
\hline 20 & 78 & 4 & 2 & 254 & 276 \\
\hline 20 & 81 & 4 & 2 & 235 & 248 \\
\hline 40 & 79 & 4 & 2 & 335 & 368 \\
\hline 40 & 80 & 4 & 2 & 551 & 643 \\
\hline 60 & 80 & 4 & 2 & 522 & 461 \\
\hline
\end{tabular}




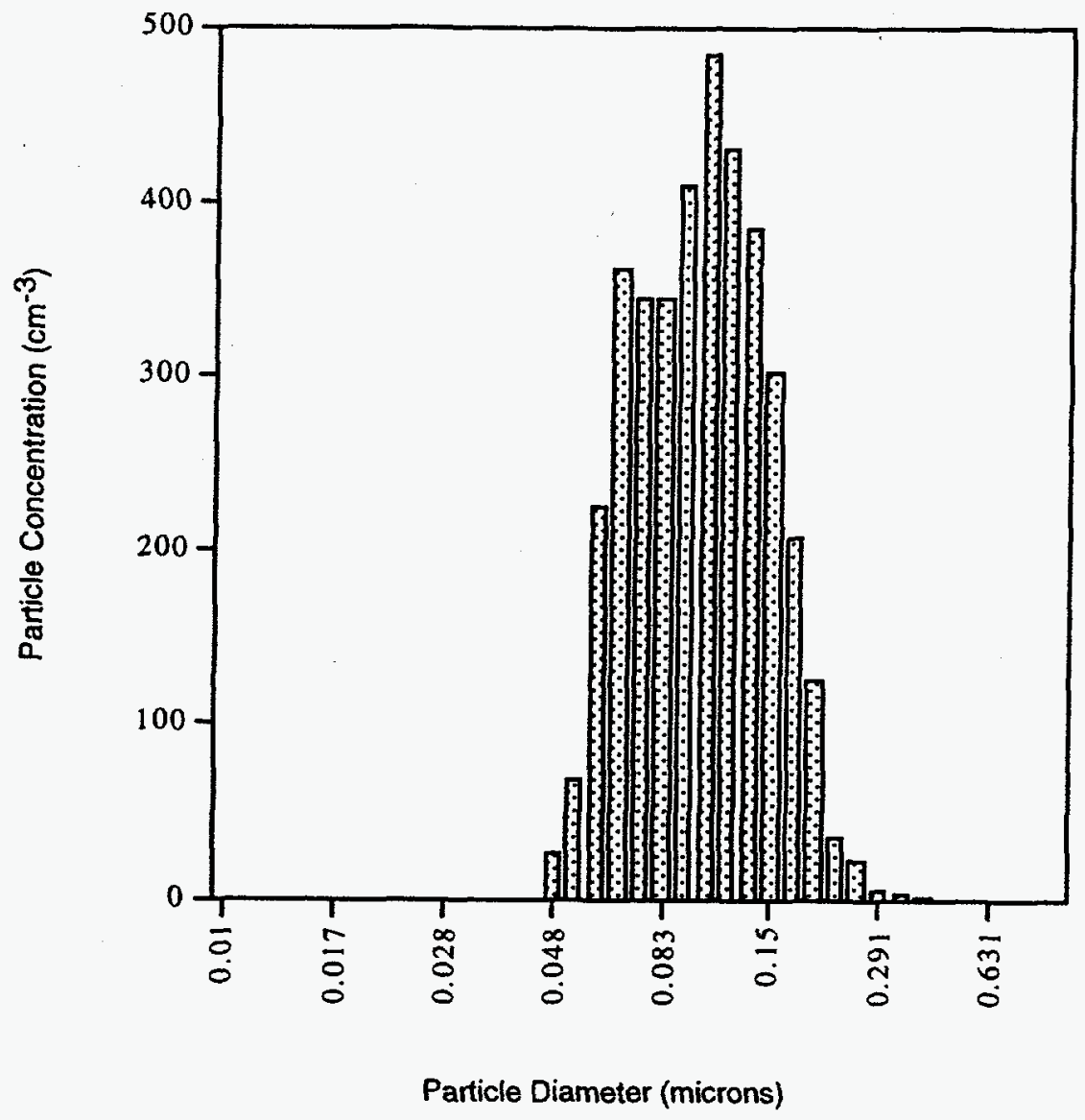

Figure A.7: Particle size distribution of 0.1 micron diameter particles for data in Table A.7. 


\section{APPENDIX B:}

SAMPLE CALCULATIONS OF PENETRATION AND ERROR 
The following procedure was used to calculate the penetration and associated error.

Given:

(Inlet Capillary)

(Outlet Capillary)

Background Counts $1=B_{1}$

Background Counts2 $=\mathrm{B}_{2}$

Raw Counts $1=\mathrm{R}_{1}$

Raw Counts2 $=R_{2}$

Detector Efficiency $1=\varepsilon_{1}$

Detector Efficiency2 $=\varepsilon_{2}$

Using the following technique for propagation of error for radioactive counts as described in Tsoulfanidis (1983).

True Counts $s_{1}=C_{1}=\frac{R_{1}-B_{1}}{\varepsilon_{1}}$

True Counts ${ }_{2}=C_{2}=\frac{R_{2}-B_{2}}{\varepsilon_{2}}$

Standard Deviation for $C_{1}=\sigma C_{1} \quad$ Standard Deviation for $C_{2}=\sigma C_{2}$

$\sigma_{\mathrm{C}_{1}}=\frac{\sqrt{\mathrm{R}_{1}+\mathrm{B}_{1}}}{\varepsilon_{1}}$

$\sigma_{\mathrm{C}_{2}}=\frac{\sqrt{\mathrm{R}_{2}+\mathrm{B}_{2}}}{\varepsilon_{2}}$

Penetration through capillary $=P=\frac{C_{2}}{C_{1}}$

Assuming the counts are directly proportional to the concentration of radio-aerosol particles collected by the filers, the standard deviation for penetration, $\sigma_{\mathrm{P}}$, may be determined from the following equation.

$$
\left(\frac{\sigma_{\mathrm{P}}}{\mathrm{P}}\right)^{2}=\left(\frac{\sigma_{\mathrm{C}_{1}}}{\mathrm{C}_{1}}\right)^{2}+\left(\frac{\sigma_{\mathrm{C}_{2}}}{\mathrm{C}_{2}}\right)^{2}+\left(\frac{\sigma_{\mathrm{B}_{1}}}{\mathrm{~B}_{1}}\right)^{2}+\left(\frac{\sigma_{\mathrm{B}_{2}}}{\mathrm{~B}_{2}}\right)^{2}
$$

This yields a capillary penetration of $P+/-\sigma_{P}$. 
APPENDIX C:

VALUES OF PENETRATION AND ERROR 
Table C.1: Penetration and error for $20 \mathrm{~min}$ sampling time at various humidities.

\begin{tabular}{||c|c|c|}
\hline \hline $\begin{array}{c}\text { Relative } \\
\text { Humidity } \\
(\%)\end{array}$ & Penetration & $\begin{array}{c}\text { Error } \\
(+/-)\end{array}$ \\
\hline \hline 22 & 1.11 & 0.16 \\
\hline 22 & 1.08 & 0.15 \\
\hline 22 & 1.12 & 0.18 \\
\hline 51 & 1.15 & 0.26 \\
\hline 51 & 0.73 & 0.16 \\
\hline 51 & 1.18 & 0.29 \\
\hline 52 & 0.86 & 0.07 \\
\hline 52 & 1.05 & 0.10 \\
\hline 78 & 0.71 & 0.07 \\
\hline 79 & 1.11 & 0.13 \\
\hline 81 & 0.77 & 0.08 \\
\hline 78 & 0.91 & 0.08 \\
\hline 81 & 0.94 & 0.09 \\
\hline
\end{tabular}


Table C.2: Penetration and error for $40 \mathrm{~min}$ sampling time at various humidities.

\begin{tabular}{|c|c|c|}
\hline $\begin{array}{c}\text { Relative } \\
\text { Humidity } \\
(\%)\end{array}$ & Penetration & $\begin{array}{c}\text { Error } \\
(+/-)\end{array}$ \\
\hline \hline 22 & 0.90 & 0.11 \\
\hline 22 & 1.06 & 0.15 \\
\hline 22 & 0.88 & 0.14 \\
\hline 24 & 1.09 & 0.11 \\
\hline 24 & 1.00 & 0.09 \\
\hline 23 & 0.92 & 0.05 \\
\hline 23 & 0.72 & 0.05 \\
\hline 25 & 0.75 & 0.09 \\
\hline 52 & 0.93 & 0.05 \\
\hline 51 & 0.95 & 0.05 \\
\hline 52 & 0.98 & 0.05 \\
\hline 83 & 0.85 & 0.06 \\
\hline 76 & 0.77 & 0.07 \\
\hline 77 & 1.05 & 0.10 \\
\hline 79 & 0.90 & 0.07 \\
\hline 80 & 0.85 & 0.05 \\
\hline & & \\
\hline
\end{tabular}


Table C.3: Penetration and error for $60 \mathrm{~min}$ sampling time at various humidities.

\begin{tabular}{||l|l|l|}
\hline \hline $\begin{array}{c}\text { Relative } \\
\text { Humidity } \\
(\%)\end{array}$ & Penetration & \multicolumn{1}{|c|}{$\begin{array}{c}\text { Error } \\
(+/-)\end{array}$} \\
\hline \hline 21 & 0.80 & 0.11 \\
\hline 23 & 0.92 & 0.10 \\
\hline 23 & 1.01 & 0.11 \\
\hline 24 & 0.85 & 0.07 \\
\hline 24 & 0.79 & 0.06 \\
\hline 23 & 0.83 & 0.07 \\
\hline 51 & 0.88 & 0.05 \\
\hline 52 & 0.76 & 0.04 \\
\hline 52 & 1.02 & 0.05 \\
\hline 50 & 0.89 & 0.05 \\
\hline 51 & 1.08 & 0.05 \\
\hline 51 & 0.88 & 0.05 \\
\hline 78 & 0.89 & 0.06 \\
\hline 76 & 0.78 & 0.09 \\
\hline 80 & 1.12 & 0.07 \\
\hline
\end{tabular}


Table C.4: Penetration and error for various sampling times at a relative humidity of $50 \%$.

\begin{tabular}{|c|c|c|}
\hline $\begin{array}{c}\text { Sampling } \\
\text { Time } \\
\text { (min) }\end{array}$ & Penetration & $\begin{array}{l}\text { Error } \\
(+/-)\end{array}$ \\
\hline 20 & 1.15 & 0.26 \\
\hline 20 & 0.73 & 0.16 \\
\hline 20 & 1.18 & 0.29 \\
\hline 20 & 0.86 & 0.07 \\
\hline 20 & 1.05 & 0.10 \\
\hline 40 & 0.93 & 0.05 \\
\hline 40 & 0.95 & 0.05 \\
\hline 40 & 0.98 & 0.05 \\
\hline 60 & 0.88 & 0.05 \\
\hline 60 & 0.76 & 0.04 \\
\hline 60 & 1.02 & 0.05 \\
\hline 60 & 0.89 & 0.05 \\
\hline 60 & 1.08 & 0.05 \\
\hline 60 & 0.88 & 0.05 \\
\hline 90 & 1.08 & 0.06 \\
\hline 90 & 1.09 & 0.05 \\
\hline 90 & 0.80 & 0.04 \\
\hline 90 & 0.88 & 0.04 \\
\hline 90 & 0.95 & 0.05 \\
\hline 105 & 0.88 & 0.05 \\
\hline 105 & 0.75 & 0.04 \\
\hline 105 & 0.80 & 0.03 \\
\hline 120 & 0.94 & 0.04 \\
\hline 120 & 1.03 & 0.05 \\
\hline 120 & 0.91 & 0.05 \\
\hline 135 & 0.98 & 0.07 \\
\hline 135 & 1.25 & 0.07 \\
\hline 135 & 0.74 & 0.03 \\
\hline 135 & 0.96 & 0.07 \\
\hline
\end{tabular}




\begin{tabular}{||l|l|l|}
\hline 150 & 0.73 & 0.04 \\
\hline 150 & 0.89 & 0.05 \\
\hline 150 & 0.92 & 0.05 \\
\hline 150 & 1.00 & 0.05 \\
\hline 165 & 0.96 & 0.04 \\
\hline 165 & 0.97 & 0.06 \\
\hline 165 & 1.11 & 0.08 \\
\hline 165 & 0.45 & 0.04 \\
\hline 165 & 0.88 & 0.05 \\
\hline 180 & 0.95 & 0.07 \\
\hline 180 & 0.80 & 0.05 \\
\hline 180 & 1.23 & 0.06 \\
\hline 180 & 0.89 & 0.05 \\
\hline
\end{tabular}

